\title{
Ta'dibuna
}

Jurnal Pendidikan Islam

Vol. 2, No. 2, Oct 2013, p-ISSN: 2252-5793, hlm. 152-197

\section{Pemikiran Pendidikan Ki Hadjar Dewantara DALAM PERSPEKTIF PENDIDIKAN ISLAM}

\author{
Muthoifin1, Didin Saefuddin², Adian Husaini ${ }^{3}$ \\ ${ }^{1}$ Institut Agama Islam Negeri Surakarta \\ 2Universitas Islam Negeri Syarif Hidayatullah Jakarta \\ 3Universitas Ibn Khaldun Bogor
}

\begin{abstract}
Education is the guidance in the growth of children's lives so that they can achieve salvation and happiness. Education must have a vision and a noble mission; the vision is far into the future beyond time and space, while the mission of Islamic education is on accordance to the concept of Tawheed, so that it will always relevant in every time and all conditions. Education should be based on divine revelation (al-Qur'an and al-Hadith). If education is not guided and does not display the spirit of the two ideologies, the education can be mentioned as a strange education. The focus of this research is the profile of Ki Hadjar Dewantara, his educational thought based on the perspective of Islamic education review, the research is focused on the aspects of the conception of education issues, including: basic, content and education systems. The objective was to determine the level of Ki Hadjar Islamic educational perspective. The research method used is the libraries research. By approaching to the history (Historical Approach) and biography of Ki Hadjar. While the data collection consists of primary and secondary data sources. Techniques of data analysis was using content analysis (content analysis), descriptive, comparative and inductive. These data were then analyzed for the conclusions drawn from the phenomena, with the steps: topic selection, collection of data sources, verification, interpretation, and historiography. The results of the study. 1, the concept of education Ki Hadjar focused on aspects of guidance to children in order to achieve happiness based on the nature of nature. This is not consistent with the concept of Islamic education that focused on aspects of worship and Tawheed based on divine revelation. 2, Ki Hadjar's basic education is the principle Pancadarma (five principles), which of the five principle is explicitly no principle of divinity, it is contrary to basic Islamic education which is based on al-Quran and al-Sunnah. 3), the Content or the essence of Ki Hadjar's education is character, humanism, freedom, natural culture. It is also incompatible with the core content of Islamic education Faith-monotheism, worship and noble character divine revelation. 4) Ki Hadjar's education system, good goals, curriculum, methods, teachers, students and the evaluation does not lead and is tied to the value of faith and worship, it is also not in line with the Islamic education system has always associate with both religious values. 5, Ki Hadjar's educational thought is nationalist-secular. Nationalists, because based on the culture of the nation, while secular because it is not linked with the spirit of the teachings of Islam (monotheism). Recognizing the importance of education, the study recommends to the government, the union and the school administrators Tamansiswa, should give attention and progressive education by applying basic, content, objectives, methods and curriculum grounded
\end{abstract}


in a principled framework and closely linked to religion and morals of Islam and develop Ki Hadjar faith-based thinking piety.

Keywords: education concept, education objectives, Islamic education, character education, character, akhlaq, values, morality

\section{PENDAHULUAN}

\section{A.Latar Belakang Masalah}

Menurut Abuddin Nata, membicarakan masalah pendidikan pada umumnya serta pendidikan Islam pada khususnya di Indonesia tidak dapat ditinggalkan pembicaraan terhadap tokoh yang bernama Ki Hadjar Dewantara, seorang pakar yang berkecimpung dan mengonsentrasikan keahliannya dalam bidang pendidikan. Hal yang demikian itu disebabkan berbagai konsep strategis tentang pendidikan di Indonesia hampir seluruh aspeknya senantiasa merujuk pada pemikirannya.[1]

Sedangkan menurut Abdurrahman Suryomiharjo, seorang sejarahwan: "Ki Hadjar Dewantara dikenal secara luas baik di dalam maupun di luar negeri. Ia dikenal karena perannya dalam pendidikan nasional yang tidak bisa dilupakan oleh bangsa Indonesia".[2]

Moch. Tauchid, seorang aktifis Tamansiswa dalam bukunya berjudul Ki Hadjar Dewantara Pahlawan dan Pelopor Pendidikan Nasional menyatakan:

Cita-cita Ki Hadjar telah berhasil turut menjiwai sistem pendidikan nasional kita pada khususnya dan perjuangan bangsa Indonesia pada umumnya. Hal ini, sama sekali tidak berarti bahwa kita mengurangi arti ataupun mengecilkan sumbangan dan peranan perjuangan tokoh-tokoh pendidikan nasional yang lain, yang juga telah merintis jalan ke arah terwujudnya pendidikan nasional berdasarkan Pancasila.[3]

Lebih lanjut Moch. Tauchid menyatakan:

Meskipun banyak pro dan kontra tanggal lahirnya Ki Hadjar dijadikan hari pendidikan nasional, sesungguhnya ketetapan tersebut sudah tepat, karena berkat konsepsi Ki Hadjar dibidang pendidikan antara lain: Teori Tripusat Pendidikan, Sistem Among, Tut Wuri Handayani, Pancadharma dan lainlainnya serta tex books ilmu pendidikan, telah mensejajarkan Ki Hadjar dengan tokoh-tokoh pendidikan dunia, seperti Frobel, Montessorie, Peztalozzi, John Dewey, Rabindranat Tagore, dan lain-lain. Yang kita warisi jasajasa dan jiwa pendidik Ki Hadjar yang tidak memihak golongan, tetapi bersifat nasional bukan Tamansiswanya.[4]

Nama Ki Hadjar senantiasa dikaitkan dengan pendirian lembaga pendidikan Tamansiswa serta perjuangannya melawan ordonansi sekolah liar yang ditetapkan oleh pemerintah Hindia Belanda. Kenji Tsuchiya dalam bukunya berjudul Democracy and Leadership: The Rise of the Tamansiswa Movement in Indonesia mengatakan:

Ki Hadjar adalah tokoh sejarah yang dikenal oleh seluruh masyarakat Indonesia. Jasanya yang tak ternilai di dalam pendidikan nasional tidak pernah akan dilupakan oleh bangsa Indonesia. Nama Ki Hadjar senantiasa dikaitkan dengan pendirian lembaga pendidikan Tamansiswa serta perjuangannya melawan ordonansi sekolah liar yang ditetapkan oleh pemerintah Hindia Belanda.[5]

Usaha Ki Hadjar untuk menyelenggarakan pendidikan nasional dimulai pada 03 Juli 1922, dengan mendirikan Perguruan Kebangsaan Tamansiswa yang pertama di 
Yogyakarta. Pada waktu itu nama yang dipakai adalah: Nationaal Onderwijs Instituut Tamansiswa. Sejak saat didirikan perguruan tersebut, nama Ki Hadjar tidak dipisahkan lagi dari Tamansiswa.[6] Abdurrahman Suryomiharjo mengungkapkan:

Ki Hadjar adalah bapak Tamansiswa, bapak pendidikan nasional. Sudah barang tentu usahanya menyelenggarakan perguruan nasional itu merupakan perjuangan yang sangat berani, karena pendidikan yang diselenggarakan oleh Pemerintah Belanda adalah pendidikan kolonial".[7]

Sejalan dengan Abdurrahman Suryomiharjo, Abuddin Nata juga mengungkapkan, Ki Hadjar menginginkan agar pendidikan yang diberikan ke bangsa Indonesia adalah pendidikan yang dilaksanakan oleh bangsa Indonesia sendiri dan didasarkan pada semangat nasionalisme, patriotisme serta membangun jati diri bangsa sebagai manusia merdeka, bebas, bermartabat dan dihormati bangsa lain.[8]

Abuddin Nata menambahkan, berbagai aspek yang terkait dengan pendidikan seperti visi, misi, tujuan, kurikulum dan tahapan pendidikan harus dirumuskan berdasarkan kemauan bangsa Indonesia sendiri. Gagasan dan pemikiran Ki Hadjar Dewantara inilah yang kemudian menjadi acuan penyelenggaraan pendidikan nasional hingga sekarang.[9]

Bahkan gagasan dan pemikiran pendidikan Ki Hadjar yang sudah ditulis dalam berbagai karangannya mendapat sambutan hangat dari kepala Negara Presiden Republik Indonesia pertama Ir. Soekarno.[10] Gagasan tentang prinsip pendidikan yang berbunyi Ing ngarso sung tulodo, Ing madya mangun karso, Tut wuri handayani.[11] adalah berasal dari buah pemikirannya.[12]

Konsep Trilogi kepemimpinan Ki Hadjar yang berbunyi Ing Ngarso Sung Tulodo, Ing Madyo Mangun Karso, Tut Wuri Handayani ini, menurut Ki Priyo Dwiarso, anggota Majlis Luhur Persatuan Tamansiswa, mengandung maksud bahwa tanpa keteladanan pimpinan di depan (ing ngarso), pro aktif mengikuti dinamika dalam masyarakat (ing madyo), dan kemudian menerapkan pembinaan atau pengawasan melekat (tut wuri), maka pemahaman dan pelaksanaan pendidikan memerdekakan jiwa masyarakat mustahil dapat tercapai.[13] Sedangkan Amir Tengku Ramly mengartikan Ing Ngarso Sung Tulodo artinya Ing ngarso itu didepan/dimuka, Sung berasal dari kata Ingsun yang artinya saya, Tulodo berarti tauladan. Jadi makna Ing Ngarso Sung Tulodo adalah menjadi seorang pemimpin harus mampu memberikan suri tauladan bagi bawahan atau anak buahnya. Sehingga yang harus dipegang teguh oleh seorang pemimpin adalah kata suri tauladan. Sebagai seorang pemimpin atau komandan harus memiliki sikap dan perilaku yang baik dalam segala langkah dan tindakannya agar dapat menjadi panutan bagi anak buah atau bawahannya.[14]

Ing Madyo Mangun Karso. "Ing Madyo" artinya di tengah-tengah, Mangun berarti membangkitan atau menggugah dan Karso diartikan sebagai bentuk kemauan atau niat. Jadi makna dari kata Ing Madyo Mangun Karso adalah seorang pemimpin ditengah kesibukannya harus juga mampu membangkitkan atau menggugah semangat kerja anggota bawahanya. Karena itu seorang pemimpin juga harus mampu memberikan inovasi-inovasi dilingkungan tugasnya dengan menciptakan suasana kerja yang lebih kodusif untuk keamanan dan kenyamanan kerja.

Tut Wuri Handayan.[15] semboyan ini berarti "mengikuti di belakang sambil memberi pengaruh", Ki Hadjar menyatakan:

... Semboyan Tut Wuri Handayani ini berarti "mengikuti di belakang sambil memberi pengaruh" Maksudnya adalah, jangan menarik-narik anak dari depan, biarkanlah mereka mencari jalan sendiri, kalau anak- 
anak salah jalan barulah si pamong (guru) boleh mencampurkan dirinya.[16]

Berdasakan keterangan di atas bahwa Tut Wuri Handayani berarti mengikuti dari belakang, tetapi tidak melepaskan anak-anak didik dari pengawasan. Maksud "berjalan di belakang" adalah memberi kebebasan kepada anak-anak untuk melatih mencari jalan sendiri. Sedangkan sebagai pendidik wajib memberi koreksi apabila dipandang perlu, misalnya bila anak menghadapi bahaya yang tak dapat dihindarinya dengan fikiran atau tenaga sendiri. Kebebasan pada anak didik inilah yang menurut Ki Hadjar Dewantara merupakan sebenar-benarnyanya demokrasi, sedangkan pimpinan yang wajib terus mengawasi tidak lain daripada kebijaksanaan sang pamong.[17]

Begitu juga konsep Sistem Among (sistem pengajaran) dan Kodrat Alam (kehendak alam) juga merupakan buah gagasan dari pemikirannya.[18] Sistem Among adalah suatu sistem pendidikan yang berjiwa kekeluargaan yang bersendikan kodrat alam dan kemerdekaan. Sistem Among ini berdasarkan cara berlakunya disebut sistem Tut wuri Handayani. Dalam sistem ini orientasi pendidikan adalah pada anak didik, yang dalam terminologi baru disebut student centered.[19] Sedangkan Kodrat alam, menurut Ahmad Sholeh dalam bukunya berjudul Relevansi Gagasan Sistem Among dan Tri Pusat Pendidikan Ki Hadjar Dewantara terhadap Pengembangan Pendidikan Islam di Indonesia, adalah perwujudan dari kekuasaan Tuhan yang mengandung arti, bahwa pada hakekatnya manusia sebagi mahluk Tuhan adalah satu dengan alam lain. Karena itu manusia tidak dapat lepas dari kehendak kodrat alam. Manusia akan memperoleh kebahagiaaan jika ia mampu menyatukan diri dengan kodrat alam yang mengandung segala hukum kemajuan. Manusia mempunyai multi potensi yang harus digali sehingga ia sadar dan berbahagia dengan kodratnya.[20]

Ki Hadjar juga seorang tokoh pendidikan yang sangat menghargai manusia. Hal demikian dapat ditemui dalam tujuan pendidikannya yang menghendaki terbentuknya manusia merdeka, sebagaimana pernyataan Bambang Sukowati Dewantara:

Manusia merdeka adalah tujuan pendidikan Tamansiswa. Merdeka baik secara fisik, mental dan kerohanian. Merdeka untuk membangun budayanya sendiri, jalan hidup sendiri dengan mengembangkan rasa merdeka dalam hati setiap orang melalui media pendidikan yang berlandaskan pada aspek-aspek nasional.[21]

Sedangkan dasar pendidikan yang dipakai Ki Hadjar dalam melaksanakan pendidikannya sebagaimana yang diterapkan di Tamansiswa adalah pendidikan yang berdasarkan pada lima asas yang disebut "Pancadarma" yaitu: 1) asas kemerdekaan, 2), asas kebangsaan, 3) asas kemanusiaan, 4) asas kebudayaan, dan 5) asas kodrat alam.[22]

Budi pekerti adalah ruh dari isi pendidikannya, sebagaimana diungkapkan Abdurrahman Surjomihajo, bahwa Ki Hadjar menganggap adab atau keluhuran budi manusia itu menunjukkan sifat batinnya manusia, sedangkan kesusilaan atau kehalusan itu menunjukkan sifat hidup lahiriyah manusia yang serba halus dan indah, atau sering dipakai kata-kata etis dan estetis yang menunjukkan dua sifat manusia yang luhur dan halus atau indah.[23]

Corak pendidikan yang digagasnya adalah suatu dasar pendidikan yang berbentuk nasionalistik dan universal, sebagaimana diungkapkan Bambang Sukowati dalam bukunya berjudul Ki Hadjar Dewantara Ayahku: 
...Landasan filosofisnya nasionalistik dan universalistik. Nasionalistik maksudnya adalah budaya nasional, bangsa yang merdeka dan independen baik secara politis, ekonomis, maupun spiritual. Universal artinya berdasarkan pada hukum alam (natural law), segala sesuatu merupakan perwujudan dari kehendak Tuhan.[24]

Ki Hadjar yang selama ini dijadikan sebagai tokoh pendidikan di Indonesia, ternyata oleh sebagaian pengamat pendidikan dan aktifis Islam disebut belum memadukan atau mengintegrasikan antara konsep pendidikan yang ia gagas dengan konsep pendidikan Islam. Hamka, dalam bukunya berjudul: Perkembangan Kebatinan di Indonesia, yang dikutip Artawijaya menyatakan:

Bahwa Tamansiswa adalah gerakan abangan, klenik, dan primbon Jawa, yang menjalankan ritual shalat daim. Dalam kepercayaan kebatinan, shalat di sini bukan bermakna ritual seperti yang dijalankan umat Islam, tetapi shalat dalam pengertian kebatinan, yaitu menjalankan kebaikan terus menerus. Inilah yang dimaksud dengan shalat daim.[25]

Sedangkan Bung Karno menyebut apa yang dilakukan oleh Ki Hadjar adalah berangkat dari panggilan mistik, sebagaimana ungkapan Bung karno yang dikutip Artawijaya:

Apa yang dilakukan oleh Ki Hadjar Dewantara adalah berangkat dari panggilan mistik. Sebuah small group discussion yang membicarakan tentang kebatinan, yang diselenggarakan setiap Selasa Kliwon dan dipimpin oleh Pangeran Soeryamataram adalah cikal bakal berdirinya Taman Siswa. Peserta diskusi kebatinan ini mendapat sebutan ketika itu dengan "Gerombolan Seloso Kliwon". Mereka adalah, Ki Hadjar Dewantara, R.M Soetatmo Soerjokoesoemo, R.M.H Soerjo Poetro, Ki Pronowidigdo, Ki Sutopo Wonoboyo, Ki Surjodirjo, BRM Subono, dan Pangeran Soeryamataram. Setiap pertemuan, mereka mendiskusikan hal-hal yang berkaitan dengan kebatinan, yaitu usaha untuk "membahagiakan diri, membahagiakan bangsa, dan umat manusia." Inilah yang menjadi asas Taman Siswa yaitu perpaduan antara pendidikan Barat dan kebatinan dalam mewujudkan suatu kemerdekaan batin, kemerdekaan pikiran dan kemerdekaan tenaga.[26]

Selanjutnya berkaitan dengan kebatinan Ki Hadjar sendiri dalam bukunya berjudul Asas-asas dan Dasar-dasar Taman Siswa, mengungkapkan:

... Maka tiap-tiap pendidikan berkewajiban memelihara dan meneruskan dasar-dasar dan garis-garis hidup yang terdapat dalam tiap-tiap aliran kebatinan dan kemasyarakatan, untuk mencapai keluhuran dan kehalusan hidup dan kehidupan menurut masing-masing aliran yang menuju ke arah adab kemanusiaan. Pendidikan dan pengajaran rakyat sebagai usaha untuk mempertinggi dan menyempurnakan hidup dan penghidupan rakyat, adalah kewajiban negara yang oleh pemerintah harus dilakukan sebaik-baiknya dengan mengingati atau memperhatikan segala kekhususan dan keistimewaan yang bertali dengan hidup kebatinan dan kemasyarakatan yang sehat dan kuat, serta memberi kesempatan pada tiap-tiap warga negara untuk menuntut kecerdasan budi, pengetahuan dan kepandaian yang setinggi-tingginya menurut kesanggupannya masing-masing.[27] 
Meskipun demikian, sebagian tokoh pendidikan juga menganggap bahwa Ki Hadjar adalah seorang muslim yang taat dan tinggal dalam lingkungan budaya Jawa yang kental, sebagaimana diungkapkan Abuddin Nata:

... Sebagai seorang Muslim yang taat dan tinggal dalam lingkungan budaya

Jawa yang kental, maka dapat diduga kuat, bahwa pemikiran Ki Hadjar itu selain dipengaruhi oleh latar belakang pendidikan, situasi sosial dan perjalanan hidupnya, juga dipengaruhi oleh pandangannya tentang ajaran Islam".[28]

Selanjutnya Ki Hadjar yang tanggal lahirnya diperingati sebagai Hari Pendidikan Nasional, akhir-akhir ini ajarannya mulai banyak ditinggalkan. Sebagaimana diungkapkan Wuryadi, ketua Majelis Luhur III Bidang Pendidikan dan Kebudayaan Persatuan Taman Siswa Yogyakarta: Konsep pendidikan yang dikembangkannya di Tamansiswa pun kini terpinggirkan dan mulai banyak ditinggalkan. Pendidikan ajaran Ki Hadjar Dewantara ternyata tidak berorientasi pada kepentingan global. Pendidikan yang dikembangkan sekarang ini berbeda orientasinya.[29]

Demikian pula dalam situasi reformasi sekarang ini, konsep pendidikan di Indonesia tengah ditinjau ulang untuk kemudian dihasilkan suatu rumusan konsep pendidikan yang sesuai dengan tuntutan zaman.[30]

Melihat uraian di atas, ditemukan beberapa indikasi bahwa pemikiran Ki Hadjar Dewantara selama ini belum memadukan antara konsep pendidikan yang ia gagas dengan konsep pendidikan Islam yang berlandaskan tauhid dan keimanan. Apalagi Indonesia adalah negara dengan jumlah penduduk yang mayoritas penghuninya beragama Islam. Tentunya Indonesia memerlukan konsep pendidikan yang bermuara dan bersendikan pada nilai-nilai ke-Islam-an yang diyakini mengandung kebenaran mutlak, bersifat transendental, universal dan eternal (abadi).

Sementara sosok Ki Hadjar, yang tanggal lahirnya (02 Mei) dijadikan sebagai Hari Pendidikan Nasional di Indonesia, dan beberapa konsep serta pemikiran pendidikannya banyak dijadikan sumber rujuakan pendidikan nasional di Indonesia, kini pemikiran dan konsep tersebut mulai banyak ditinggalkan. Bahkan konsep pendidikan yang dikembangkan di Tamansiswa pun kini terpinggirkan.

Dengan demikian, permasalahan yang mendasar dilakukannya penelitian ini adalah untuk mengungkap pemikiran pendidikan Ki Hadjar Dewantara yang berdasarkan Pancadharma, dengan konsep pendidikan Islam yang berdasarkan pada nilainilai Ilahiyah yang inti ajarannya tauhid, sehingga penulis akan membaca dan menganalisis pemikiran Ki Hadjar tersebut dengan pendekatan pendidikan Islam. Untuk itu penulis mengangkat tema tersebut dan memberi judul Pemikiran Pendidikan Ki Hadjar Dewantara Perspektif Pendidikan Islam.

\section{METODOLOGI}

\section{A. Jenis Penelitian}

Jenis penelitian yang digunakan dalam penulisan ini adalah studi pustaka (library research), karena cara mengumpulkan data melalui peninggalan tertulis, terutama berupa arsip-arsip dan termasuk juga buku-buku tentang pendapat, teori, dalil/hukum-hukum dan lain-lain yang berhubungan dengan pokok permasalahan sebagai sumber primer, baik dari karya-karya Ki Hadjar sendiri maupun sumbersumber data lain yang relevan dengan masalah penelitian ini.[38]

Studi ini juga dikategorikan sebagai penelitian kualitatif. Dikatakan kualitatif, karena studi ini lebih menekankan pada pendeskripsian pemikiran pendidikan Ki 
Hadjar Dewantara, terutama pemikiran pendidikannya jika ditinjau dari perspektif pendidikan Islam. Karena fokusnya pada deskriptif, maka penelitian ini juga bersifat alamiah dan induktif. Sebagaimana diungkapkan Bodgan dan Biklen, bahwa penelitian kualitatif memiliki lima karakteristik khusus, yaitu: (a) naturalistik, (b) deskriptif, (c) perhatian pada proses, (d) induktif, dan (e) perhatian pada makna.[39]

B. Pendekatan

Pendekatan yang digunakan dalam penelitian ini adalah pendekatan sejarah (Historical Approach). Historis atau sejarah adalah suatu ilmu yang di dalamnya dibahas berbagai peristiwa dengan memperhatikan unsur tempat, waktu, obyek, latar belakang, dan pelaku dari peristiwa tersebut.[40] Sedangkan menurut Endin Mujahidin, penelitian sejarah adalah metode atau cara yang digunakan sebagai pedoman dalam melakukan penelitian peristiwa sejarah dan permasalahannya. Dengan kata lain metode penelitian sejarah adalah instrumen untuk merekonstruksi peristiwa sejarah (history as past actuality) menjadi sejarah sebagai kisah (history as written).[41] Studi ini dilakukan dengan cara menelusuri berbagai literatur atau dokumen untuk mendapatkan kejelasan teoritis mengenai konsep atau teori-teori seputar pemikiran pendidikan tokoh yang jadi obyek, sekaligus sebagai upaya untuk melacak berbagai penjelasan tekstual dan historis tentang penelitian ini baik yang berupa akademik murni maupun hasil studi lapangan.

Pendekatan lain dalam penelitian ini adalah pendekatan biografi. Pendekatan biografi adalah pendekatan dengan membicarakan, memaparkan tentang pemikiran atau pun pandangan tokoh, agamawan, politikus, ataupun sejarawan. Pendekatan ini akan digunakan dalam meneliti kehidupan Ki Hadjar sehingga dapat diungkap segi historisnya, latar belakang sosial budaya, aliran pemikiran, pengaruh ideologi, dan lain-lain. Hal tersebut mengingat pemikiran yang lahir dari tokoh adalah hasil dialektika individu tersebut dengan pemahaman agama, realitas sosial, budaya, dan pengalaman politiknya.[42]

Selain itu, penulis juga memakai pendekatan normatif, yaitu pendekatan untuk merumuskan kesimpulan-kesimpulan mengenai keadaan dan kaidah yang berlaku pada obyek penelitian. Atau dengan cara pendekatan terhadap masalah yang diteliti dengan menjelaskan mengenai pendapat-pendapat yang ada tentang obyek yang diteliti.[43]

C. Sumber Data

\section{Data Primer}

Sumber data primer atau tangan pertama.[44] yaitu: data yang diperoleh langsung dari subyek penelitian dengan mengenakan alat pengukur atau alat pengambilan data langsung pada subyek sebagai sumber informasi yang dicari.[45] Data primer dalam penelitian ini mengunakan karya-karya yang ditulis langsung oleh Ki Hadjar. Diantaranya:

- Karya Ki Hadjar Dewantara: Bagian Pertama Pendidikan, Yogyakarta: Percetakan Majlis Luhur Taman Siswa, 1962.

- Karya Ki Hadjar Dewantara: Bagian Kedua Kebudayaan, Yogyakarta: Percetakan Majlis Luhur Taman Siswa, 1967.

- Asas-asas dan Dasar-dasar Taman Siswa, Yogyakarta: Majlis Luhur Taman Siswa, 1961.

- Pengaruh Keluarga terhadap Moral, Jakarta: Endang, 1951.

- Taman Indrya (Kindergarten), Yogyakarta: Majlis Luhur Taman Siswa, 1959.

- Demokrasi dan Leiderschap, Yogyakarta: Majlis Luhur Taman Siswa, 1959. 
- Kenang-kenangan Ki Hadjar Dewantara: dari Kebangunan Nasional sampai Proklamasi Kemerdekaan, Jakarta: Penerbit Endang, 1952.

Untuk mendukung sumber primer tersebut, peneliti melakukan wawancara langsung dengan tokoh dan pakar di Perguruan Tamansiswa Yogyakarta, terkait pemikiran Ki Hadjar tentang pendidikan.

2. Data Sekunder

Sumber data sekunder atau data tangan kedua, adalah: data yang diperoleh dari pihak lain, tidak langsung diperoleh oleh peneliti dari subyek penelitiannya.[46] Data sekunder yang digunakan dalam penelitian ini adalah karyakarya penyusun lain yang berkaitan erat dengan tema penelitian ini baik berupa buku, artikel, maupun karya lain. Data sekunder ini diperoleh melalui penelusuran literatur, dokumen atau data-data lain yang berkaitan dengan obyek penelitian.

D. Teknik Analisis Data

Data-data yang telah terkumpul agar mudah ditarik kesimpulan, maka diolah dalam bentuk:

\section{A. Content analysis}

Content analysis (analisis isi), yaitu: Menganalisis data sesuai dengan kandungan isinya. Dengan ini data-data yang penulis kumpulkankan adalah bersifat deskriptif dan data tekstual yang bersifat fenomenal, maka dalam mengelola data-data tersebut penulis menggunakan analisis ini, sebagaimana dikatakan Sumardi Suryabrata sebagai Content analysi.[47] Dengan analisis ini penulis akan melakukan analisis data secara ilmiah dan menyeluruh tentang konsepsi pendidikan Ki Hadjar.

B. Komparatif

Komparataif yaitu: Metode dengan cara membandingkan dua atau tiga kejadian dengan melihat penyebab-penyebabnya.[48] Teknik ini dipakai sebagai upaya perbandingan untuk memperoleh hasil maksimal yang komprehensif.

C. Deskriptif

Deskriptif adalah: Penggambaran suatu metode atau proses pemecahan masalah yang diselidiki dengan membuat penggambaran secara sistemis, faktual dan akurat.[49] Dalam hal ini penulis memandang fenomena-fenomena secara tekstual maupun kontekstual pemaknaan (interpretasi) pemikiran pendidikan Ki Hadjar dengan berbagai pertimbangan ruang dan waktu. Selanjutnya disimpulkan dalam bentuk disertasi dengan kalimat yang mudah dimengerti.

D. Induktif

Analisis data induktif yaitu: Penelitian dengan melakukan abstraksi dari data yang terkumpul serta mencari pola-pola umum dari data tersebut. Analisis ini dilakukan tidak menunggu sampai dengan pengumpulan data selesai, dengan kata lain analisis ini dilakukan secara paralel pada saat pengumpulan data, cara ini juga dapat diartikan sebagai analisa yang menggunakan data-data empiris, data-data itu kemudian dianalisa, ditafsirkan, dipelajari, dan diambil kesimpulan dari fenomena yang ada di lapangan.[50]

Selanjutnya, karena penelitian ini merupakan studi tokoh dan sejarah, maka langkah-langkah yang digunakannya meliputi: a) pemilihan topik, b) pengumpulan sumber, c) verifikasi (kritik sejarah, keabsahan sumber), d) 
interpretasi (analisis dan sintesis), e) historiografi atau penulisan, dan f) penyimpulan.

\section{HASIL DAN PEMBAHASAN}

B.Analisis Pendidikan Ki Hadjar Dewantara Perspektif Pendidikan Islam

Dalam bab sebelumnya sudah dijelaskan bahwa pendidikan menurut Ki Hadjar adalah sebagai tuntunan di dalam hidup tumbuhnya anak-anak. Maksudnya adalah menuntun segala kekuatan kodrat yang ada pada anak-anak itu agar mereka sebagai manusia dan sebagai anggota masyarakat dapat mencapai keselamatan dan kebahagiaan yang setingi-tinginya.[58]

Menurut UU No. 20 tahun 2003, Pendidikan adalah usaha sadar dan terencana untuk mewujudkan suasana belajar dan proses pembelajaran agar peserta didik secara aktif mengembangkan potensi dirinya untuk memiliki kekuatan spiritual keagamaaan, pengendalian diri, kepribadian, kecerdasan, akhlak mulia, serta ketrampilan yang diperlukan dirinya, masyarakat, bangsa, dan Negara.[59]

Sedangkan pengertian pendidikan Islam adalah bimbingan atau arahan yang diberikan oleh seseorang kepada seseorang lain agar ia berkembang secara maksimal sesuai dengan ajaran Islam dan nilai-nilai fundamental yang terkandung dalam sumber dasarnya, yaitu al-Qur'an dan al-Sunnah.60]

Memperhatikan pengertian tersebut di atas, menurut analisa penulis ditemukan adanya kemiripan, sekaligus ketidaksesuaian antara pengertian pendidikan Ki Hadjar dengan pengertian pendidikan Islam. Persamaannya secara eksplisit terdapat pada prosesnya, yaitu menuntun atau membimbing seseorang. Hal ini mengandung maksud bahwa pendidikan Ki Hadjar dan pendidikan Islam adalah upaya untuk memberi tuntunan atau bimbingan kepada seseorang.

Sedangkan ketidaksesuaiannya terletak pada landasan atau pijakan dalam proses pembelajaran. Dimana dalam kependidikan Islam, pendidikan harus sesuai dengan ajaran Islam dan nilai-nilai fundamental yang terkandung dalam sumber Islam yaitu al-Qur'an dan al-Sunnah. Mengingat nilai-nilai dasar dan ajaran dalam pendidikan Islam sangat memperhatikan sumbernya, yaitu semuanya harus bersumber pada wahyu Ilahiyah (al-Qur'an dan al-Sunnah), sedangkan sumber dasar pada pendidikan Ki Hadjar berlandaskan pada garis-garis kodrat pribadi seseorang dan pengaruh keadaan yang mengelilingi dirinya. Hal yang demikian dikarenakan, Ki Hadjar menghendaki agar kelak dalam garis-garis kodrat pribadinya dan pengaruh segala keadaan yang mengelilingi dirinya, anak-anak didik dapat kemajuan alam hidupnya lahir dan batin.

C.Analisis Dasar Pendidikan Ki Hadjar Perspektif Pendidikan Islam

Dasar atau asas pendidikan adalah pandangan hidup yang melandasi seluruh aktifitas pendidikan. Karena dasar pendidikan menyangkut masalah ideal dan fundamental, maka diperlukan landasan pandangan hidup yang kokoh dan komprehensif serta tidak mudah berubah karena diyakini memiliki kebenaran yang telah teruji oleh sejarah. Kalau nilai-nilai sebagai pandangan hidup yang dijadikan landasan pendidikan itu bersifat relatif dan temporal, maka pendidikan akan mudah terombang ambing oleh kepentingan dan tuntutan sesaat yang bersifat teknis dan pragmatis.[61] Seperti pendidikan Islam, dimana pendidikan ini dasar atau asasnya bersumberkan pada wahyu Ilahiyah yaitu al-Quran dan al-Hadits, sedangkan inti sari dari ajaranya adalah keimanan, amaliah, ilmiah, akhlak dan sosial.[62] 
Achmadi menyatakan, bahwa Islam sebagai pandangan hidup yang berdasarkan nilai-nilai Ilahiyah, baik yang termuat dalam al-Qur'an maupun Sunnah Rasul diyakini mengandung kebenaran mutlak yang bersifat transendental, universal dan eternal (abadi), sehingga secara akidah diyakini oleh pemeluknya akan selalu sesuai dengan fitrah manusia, artinya memenuhi kebutuhan manusia kapan dan dimana saja (likulli zamanin wa makanin).[63]

Berdasarkan uraian di atas dapat dipahami bahwa pendidikan Islam adalah upaya normatif yang berfungsi untuk memelihara dan mengembangkan fitrah manusia, maka harus didasarkan pada nilai-nilai tersebut diatas dalam menyusun teori maupun praktik pendidikan.

Lantas bagaimana dengan dasar pendidikan Ki Hadjar?. Seperti yang sudah disebutkan pada bab IV bahwa Ki Hadjar juga mempunyai dasar tersendiri dalam pelaksanaan pendidikannya, yaitu suatu dasar yang berasaskan pada lima asas atau lebih dikenal dengan sebutan (Pancadarma). Pancadarma ini memuat lima asas yang sangat fundamental, dimana ia merupakan dasar yang harus dilaksanakan dalam proses pendidikan. Kelima asas itu terdiri dari: 1) asas kemerdekaan, 2), asas kebangsaan, 3) asas kemanusiaan, 4) asas kebudayaan, dan 5) asas kodrat alam. Sedangkan dasar-dasar lain yang digunakan dalam kelangsungan pendidikan di perguruannya Ki Hadjar menambahkan tujuh dasar. ketujuh dasar itu berupa sebuah rangkaian cita-cita pendidikan yang memuat tujuh pasal, dimana lima dari tujuh pasal itu merupakan cerminan atau intisari dari asas pendidikan Tamansiswa (Pancadarma).

Berikut Pancadarma yang dirangkai oleh Ki Hadjar dalam sebuah kalimat yang berbunyi:

Berilah (Kemerdekaan) dan kebebasan kepada anak-anak kita; bukan kemerdekaan yang leluasa, namun yang terbatas oleh tuntutantuntutan (Kodrat alam) yang hak atau nyata dan menuju ke arah (Kebudayaan), yakni keluhuran dan kehalusan hidup manusia, agar kebudayaan tadi dapat menyelamatkan dan membahagiakan hidup dan penghidupan diri dan masyarakat, maka perlulah dipakainya dasar (Kebangsaan), akan tetapi jangan sekali-kali dasar ini melanggar atau bertentangan dengan dasar yang lebih luas, yaitu dasar (Kemanusiaan).[64]

Melihat uraian di atas, akan tampak jelas gambaran antara dasar pendidikan Ki Hadjar dengan dasar pendidikan Islam jika dilihat dalam suatu tabel.

Adapun tinjauan pendidikan Islam terhadap keterangan Asas-asas Pancadarma adalah sebagai berikut:

1. Asas Kemerdekaan

Hal ini mengandung arti bahwa Tamansiswa tidak boleh bertentangan dengan asas kemerdekaaan. Sebagaimana gambaran Ki Hadjar yang menghendaki bahwa kemerdekaan adalah kodrat alam kepada semua mahluk manusia yang memberikan kepadanya hak "swa-wasesa" dengan selalu mengingati syarat-syarat tertib damainya hidup bersama. kemerdekaan di sini harus diartikan "swa-disiplin" atas dasar nilai hidup yang tinggi, baik hidup sebagai individu maupun sebagai anggota masyarakat. Kemerdekaan harus juga menjadi dasar untuk mengembangkan pribadi yang kuat dan sadar dalam suasana perimbangan dan keselarasan dengan masyarakatnya.[65]

Menurut penulis, kemerdekaan dalam penyelenggaraan pendidikan $\mathrm{Ki}$ Hadjar berarti memberikan kebebasan yang profesional kepada anak didik 
dalam berpikir dan berbuat untuk mencapai cita-citanya, itulah sebabnya tujuan pendidikan Tamansiswa adalah mengembangkan dan membangun orang yang dapat berpikir dan berbuat secara merdeka, lahir dan batin. Maka dalam pendidikan harus senantiasa diingat bahwa kemerdekaan itu sifatnya berdiri sendiri, dapat mengatur diri sendiri, dan tidak bergantung kepada orang lain.

Dengan merumuskan asas kemerdekaan ini, menurut penulis Ki Hadjar memaksudkannya sebagai kritik terhadap sistem pendidikan Barat yang dinilainya terlalu bersifat intelektualitas karena dikembangkan atas asas perintah, ketertiban, dan hukuman. Sedangkan Tamansiswa, sejak awal berdirinya mengutamakan semangat tertib dan tenteram, dengan metode Among "Mengemong" sebagai metode pendidikannya, sehingga muncul tradisi dalam praktek kependidikan sehari-hari, bahwa mengekang kemerdekaan siswa berarti menghambat kemajuan dan perkembangan mereka.

Menurut penulis, jika dilihat dari sudut pendidikan umum, maka asas kemerdekaan yang terdapat dalam Pancadarma sesungguhnya merupakan sesuatu yang pantas untuk diambil manfaatnya bagi kepentingan anak didik dalam arti yang luas, karena pada prinsipnya aktifitas pendidikan juga memberikan tempat utama terhadap prinsip-prinsip dasar kemerdekaan manusia.

Sedangkan menurut Sholehan, seorang peneliti dasar pendidikan Ki Hadjar, sekaligus dosen IAIN Ampel Surabaya, bahwa ajaran Islam memandang kemerdekaan sebagai hal yang bersifat natural pada manusia, tanpa kebebasan maupun kemerdekaan manusia tidak dapat diharapkan memiliki tanggung jawab atas segala perbuatannya. Seseorang dianggap bermoral, apabila dapat berbuat sesuai dengan kebebasannya, karena dari sinilah nilai moral itu berarti. Menurut ajaran Islam, setiap manusia itu dijamin kemerdekaannya sebagai sesuatu yang mendasar dan asasi. Realitas kemerdekaan yang dimiliki manusia adalah wujud dari jaminan agama Islam atas kebebasan yang bersangkutan untuk berkemauan sendiri, di mana apabila kemerdekaan tersebut terganggu, maka berarti ancaman bagi eksistensi dirinya.[66]

Sementara Hasan Langgulung mengatakan, prinsip-prinsip yang merupakan pandangan Islam tentang kebebasan dan kemerdekaan manusia adalah sebagai berikut: 1) menekankan hubungan dan keseimbangan antara prinsip kebebasan, persaudaraan, dan persamaan, 2) menekankan kebebasan dan lemah lembut, toleransi, persaudaraan, dan kasih sayang. Tetapi dengan tegas harus diatur oleh hukum, 3) menekankan kebebasan yang menyelaraskan antara kedudukan individu dan masyarakat dalam memeroleh hak masing-masing dan didorong serta dilandasi oleh akhlak dengan memperhatikan harga diri manusia, 4) kebebasan yang menyelaraskan hubungan individu dan masyarakat dengan memperhatikan unsur kemaslahatan dan hak memperoleh perlindungan hidup bersama, 5) menjamin terpenuhinya kebebasan individu dalam kehidupan sehari-hari dengan syarat tidak mengganggu ketertiban dan aturan masyarakat, dan 6) melaksanakan kebebasan dalam kerangka agama, akhlakul karimah, tanggung jawab, akal sehat, dan keindahan.[67]

Imam Zarkasyi, seorang tokoh dan pendiri Pondok Pesantren Modern Gontor dalam buku A. Susanto, Pemikiran Pendidikan Islam, Jakarta: Amzah, 2009, hlm. 145) menyatakan, pola pikir dan kebebasan yang diterapkan di pesantren ini dilakukan dengan cara pembiasaan, keteladanan, dan pengondisian ling- 
kungan, hal ini dimaksudkan untuk menanamankan jiwa bebas, merdeka, berkepribadian, dan berkeyakinan hidup.[68]

Lebih lanjut Imam Zarkasyi menegaskan, yang dimaksud dengan pola pikir bebas dan merdeka di sini adalah kebebasan yang berada dalam garis-garis disiplin yang positif dengan penuh tanggung jawab, baik dalam kehidupan pondok maupun di masyarakat. Kebebasan ini juga menghendaki santri yang memiliki jiwa berdiri di atas kaki sendiri atau berdikari. Santri bebas untuk menentukan masa depannya dengan memiliki jiwa keikhlasan dan jiwa kesedernaan dalam hidup.[69]

Tentang kebebasan, Marcel A. Boisard dalam buku L'Humanisme de L'Islam yang diterjemahkan oleh H.M. Rasjidi ke dalam Bahasa Indonesia berjudul $\mathrm{Hu}$ manisme dalam Islam menyatakan:

Kemerdekaan manusia berada dalam memilih secara berfikir untuk menghormati hukum-hukum yang diwahyukan dan mengetahui perintah-perintah Tuhan. Memilih pilihan yang bersandar kepada fikiran. Pertangjawaban pribadi yang akan dihadapi tiap orang di hari kiamat mengandung arti bahwa manusia itu diberi kemampuan untuk memilih, jadi diberi kemerdekaan. Di sinilah letak kebesaran manusia. Allah Swt berfirman dalam surat al-Tahrim ayat 7:

Hai orang-orang kafir, janganlah kamu mengemukakan uzur pada hari ini. Sesungguhnya kamu Hanya diberi balasan menurut apa yang kamu kerjakan.[70]

Lebih lanjut Marcel A. Boisard menyatakan “...perspektif hari peradilan terakhir mengandung tanggungjawab manusia, yakni bahwa manusia dapat memilih antara yang baik dan yang jahat". [71]

Sebagaimana terdapat dalam beberapa ayat al-Qur'an, di antaranya firman Allah dalam surat al-A'raf ayat 168:

$\checkmark$ Dan kami bagi-bagi mereka di dunia Ini menjadi beberapa golongan; di antaranya ada orang-orang yang saleh dan di antaranya ada yang tidak demikian. dan kami coba mereka dengan (nikmat) yang baik-baik dan (bencana) yang buruk-buruk, agar mereka kembali (kepada kebenaran).

Manusia yang merdeka dan bertanggungjawab tidak merupakan mainan di tangan Tuhan yang Maha Kuasa. Kemerdekaan dalam memilih tindakan dan tanggungjawab yang menyertainya memberikan kepada manusia keluhuran dan martabat tinggi serta menegakkan kehidupan moral. Keagungan manusia merupakan hasil dari fakta bahwa ia memilih tunduk kepada Tuhan. Oleh karena orang Mukmin percaya dan itu berhubungan langsung dengan Tuhan tanpa perantara dan tanpa intersessi (syafa'at), maka tanggungjawabnya menjadi pertanggungjawaban pribadi. Allah berfirman dalam surat al-Najm ayat 38-39:

(yaitu) bahwasanya seorang yang berdosa tidak akan memikul dosa

orang lain. Dan bahwasanya seorang manusia tiada memperoleh selain apa yang Telah diusahakannya.[72]

Melihat uraian di atas Marcel A. Boisard berpendapat bahwa manusia itu merdeka. Kalau kita ingkar akan kemerdekaan manusia, ini berarti bahwa kita mengatakan bahwa Tuhan itu tidak adil karena dia menyiksa atau memberi pahala kepada manusia atas dasar bahwa manusia itu tidak merdeka memilih sesuatu, yakni bahwa ia itu tidak bertanggungjawab.[73] Tuhan sendiri adalah kemerdekaan yang mutlak, akan tetapi kemerdekaan manusia itu walaupun han- 
ya relatif, juga tetap merupakan kemerdekaan, sebagaimana cahaya yang lemah juga merupakan cahaya. Karena manusia tidak mengetahui kehidupan yang akan datang yang disediakan oleh Tuhan baginya maka tindakan-tindakannya timbul dari keputusan yang diambil oleh kemauannya dan kepandaiannya. Jadi manusia itu merdeka dan bertanggungjawab tentang pilihannya.[74]

Akhirnya penulis menambahi, Islam berpandangan bahwa kebebasan manusia tidaklah mutlak sifatnya, sebab ia terikat oleh tanggung jawab moral untuk dirinya sendiri dan kepentingan masyarakat luas. Kemerdekaan yang hakiki adalah jika seseorang dapat menundukkan hawa nafsu dan mampu menguasai ajakan hati yang sekiranya dapat menjerumuskan ke arah jalan hidup yang menyimpang. Kemerdekaan adalah konsep yuridis sedemikian rupa yang didasari oleh ketentuan Allah, bukan sekedar atas dasar nilai moral manusia. Konsekuensinya, semua perbuatan manusia termasuk bagaimana ia menghormati kemerdekaan orang lain, sesungguhnya merupakan ekspresi semata dari ketundukannya terhadap Allah.

2. Asas Kebangsaan

Maksudnya menurut Ki Hadjar, Tamansiswa tidak boleh bertentangan dengan kemanusiaan, melainkan harus menjadi bentuk dan fiil kemanusiaan yang nyata. Oleh karena itu, kebangsaan ini tidak mengandung arti permusuhan dengan bangsa lain, melainkan mengandung rasa satu dengan bangsa sendiri, rasa satu dalam suka dan duka, rasa satu dalam kehendak menuju kepada kebahagiaan hidup lahir dan batin seluruh bangsa.[75]

Melihat uraian di atas, menurut penulis, Ki Hadjar menginginkan pendidikan nasional harus berupaya menanamkan nasionalisme sosio-kultural kepada anak didik dalam rangka meningkatkan martabat bangsa. Asas Kebangsaan dalam konsepsi ini bukanlah paham kebangsaan dalam arti sempit, tetapi merupakan jalan yang harus dipilih manusia dalam rangka menghasilkan darma yang mendorong tercapainya kemajuan di segala bidang. Asas kebangsaan semacam ini tidak bermaksud memisahkan bangsa Indonesia dari pergaulan dengan bangsa lain, tetapi justru untuk menjalin persatuan yang sama menuju tercapainya kemajuan umat manusia.

Sedangkan Islam memandang bahwa umat manusia cenderung berkelompok yang kemudian membentuk masyarakat atau bangsa-bangsa. Hal ini sejalan dengan firman Allah dalam surat al-Hujurat ayat 13:

Wahai manusia! Sungguh, Kami telah menciptakan kamu dari

seorang laki-laki dan perempuan, kemudian Kami jadikan kamu berbangsa-bangsa dan bersuku-suku agar kamu saling mengenal.

Memperhatikan ayat di atas, jelaslah bahwa masyarakat atau bangsa, menurut Islam adalah suatu kelompok atau kumpulan individu yang merupakan kesatuan kebudayaan, negara, dan agama. Di dalamnya terbentuk jalinan wujud hubungan timbal balik dan harmonis antar anggota atau warga sehubungan dengan berbagai kepentingan, adat istiadat, pola-pola kehidupan, undangundang, institusi, teknis, penyelesaian masalah dan berbagai segi yang menyangkut fenomena kehadiran masyarakat dalam pengertian yang luas.[76]

al-Syaibany menyatakan bahwa ciri-ciri masyarakat Islam adalah sebagai berikut: 1) terwujud atas dasar ikatan keimanan kepada Allah, 2) agama selalu diletakkan pada posisi yang tinggi, 3) adanya penilaian yang sangat penting terhadap akhlak dan kesusilaan dalam kehidupan, dan 4) ilmu pengetahuan memperoleh perhatian utama. 
Melihat uraian di atas, menurut penulis dapat disimpulkan bahwa titik temu antara Pancadarma (kebangsaan) dan kebangsaan dalam pandangan Islam adalah mengenai asas kemasyarakatan dan asas kebangsaan. Keduanya memandang penting bahwa untuk mencapai sesuatu yang dicita-citakan, maka individu-individu itu harus mengikatkan diri dalam sebuah masyarakat berkebangsaan. Perbedannya, konsepsi kemasyarakatan dalam Islam memiliki ciri khas sebagai kelompok individu yang berinteraksi satu sama lainnya atas dasar pandangan hidup yang sama, yaitu menerapkan nilai-nilai ajaran Islam dalam bidang keimanan, akhlak, ilmu pengetahuan, termasuk di dalamnya pendidikan.

3. Asas Kemanusiaan

Menurut Ki Hadjar asas ini mempunyai arti bahwa darma tiap-tiap manusia itu adalah mewujudkan kemanusiaan, yang berarti kemajuan kemanusiaan lahir dan batin yang setinggi-tingginya, dan kemajuan manusia yang tinggi itu dapat dilihat pada kesucian hati orang dan adanya rasa cinta kasih terhadap sesama manusia dan terhadap mahluk Tuhan seluruhnya, tetapi cinta kasih yang tidak bersifat kelembekan hati, melainkan bersifat keyakinan adanya hukum kemajuan yang meliputi alam semesta. Karena itu dasar cinta kasih kemanusiaan itu harus tampak pula sebagai kesimpulan untuk berjuang melawan segala sesuatu yang merintangi kemajuan selaras dengan kehendak alam.[77]

Dengan adanya asas kemanusiaan ini, Ki Hadjar berpedoman bahwa intisari dari pendidikan (dalam arti yang sesungguhnya) adalah proses memanusiakan manusia (humanisasi), yakni pengangkatan manusia ke taraf insani. Di dalam mendidik ada pembelajaran yang merupakan komunikasi eksistensi manusiawi yang otentik kepada manusia, untuk dimiliki, dilanjutkan dan disempurnakan. Jadi sesungguhnya pendidikan adalah usaha bangsa ini membawa manusia Indonesia keluar dari kebodohan, dengan membuka tabir aktual-transenden dari sifat alami manusia.[78]

Berdasarkan uraian di atas, nampak jelas bahwa Ki Hadjar dalam hal kemanusiaan berkesimpulan agar sifat kemanusiaan itu bisa berjuang melawan segala sesuatu yang dapat merintangi kemajuan yang selaras dengan kehendak alam, bukan kehendak Tuhan.

Sementara dalam pendidikan Islam, Islam memiliki pandangan sedemikian rupa tentang manusia dan berbagai ikhwal kemanusiaannya, diantaranya pandangan yang dikemukakan oleh Asy-Syaibani, menurutnya: 1) manusia adalah makhluk termulia dari segenap makhluk dan wujud lain di alam ini, 2) manusia diberi amanah atau taklif untuk menjadi khalifah Allah di bumi, 3) manusia sebagai makhluk sosial yang dapat berbahasa sebagai media komunikasi dan berpikir, 4) manusia dengan perwatakannya yang asli dan ciri pertumbuhannya adalah hasil pencapaian dua faktor: warisan dan lingkungan, 5) manusia memiliki motivasi, kecenderungan dan keputusan untuk berbuat sesuatu baik yang diwarisi maupun diperolehnya melalui proses sosialisasi, 6) bahwasanya manusia itu satu dengan yang lain berbeda dalam hal bakat dan kemauan, antara lain karena perbedaan dari segi keturunan dan lingkungan, dan 7) manusia memunyai keluwesan sifat yang dapat dibentuk dan diubah melalui pendidikan.

Sedangkan menurut Sholehan, bahwa implikasi terpenting yang berhubungan dengan pendidikan, khususnya berkaitan dengan prinsip dasar pandangan Islam terhadap manusia adalah: 1) sejauh mana manusia dipandang sebagai kha- 
lifah Allah di bumi, maka konsekuensinya harus memperhatikan pertumbuhan serta perkembangan individu secara harmonis agar individu tersebut mampu mengatasi tantangan alam dan lingkungannya, 2) adanya konsep fitrah, mengharuskan pendidikan Islam bertujuan untuk membimbing dan mengarahkan potensi dasar manusia ke arah yang baik dan benar, dan 3) pelaksanaan pendidikan harus memerhatikan kondisi dan karakter anak didik serta faktor lingkungannya, demikian juga waktu yang tepat untuk melangsungkan kegiatan belajar mengajar.[79]

Tentang Manusia, Marcel A. Boisard dalam buku L'Humanisme de L'Islam menyatakan:

Menurut cara berfikir dalam Islam yang dipusatkan kepada Tuhan dan al-Qur'an, nilai manusia yang sedalam-dalamnya dan sesungguhnya akan ditentukan oleh hubungannya dengan Zat yang Mutlak, dalam rangka hari kemudiannya yang langsung dan juga kekal. Pandangan Islam meliputi keseluruhan kondisi manusia. Wahyu menjelma sebagai kesatuan yang menyeluruh. Wahyu Islam mengandung perincian-perincian yang sangat banyak sehingga sesuatu penjelasan yang kurang teliti akan dapat menimbulkan pembauran. Sebaliknya jika ajaran Islam itu diterangkan secara sangat sederhana, ia dapat menimbulkan ide yang keliru tentang konsep-konsep yang pokok.[80]

Lebih lanjut Marcel A. Boisard mengatakan:

Manusia itu adalah suatu tanda yang ajaib dari kekuasaan dan rahmat Tuhan. Manusia adalah khalifah Allah di bumi. Dengan demikian dapat disimpulkan bahwa adanya manusia sebagai bukti tentang adanya Tuhan, karena Tuhan sendiri telah memberikan kedudukan yang tinggi kepada manusia itu sendiri.[81]

Masih merujuk pada pemikiran Marcel A. Boisard, bahwa konsepsi manusia dalam agama Islam sangat berbeda dengan konsepsi manusia pada agama Kristen. Dalam ajaran Islam manusia tidak dapat bersatu dengan Zat yang Mutlak, dengan jalan cinta dan pengorbanan; manusia akan tetap merupakan hanya suatu tanda yang jauh dari Tuhan dan suatu simbol yang kelihatan dari Zat yang tak dapat digambarkan. Dengan begitu, kepribadian manusia hanya merupakan suatu kesaksian perorangan dari seorang mukmin, dan dengan pendalaman ibadah, kesaksian itu mempersatukan kepribadian tersebut kepada Tuhan yang disembahnya dengan praktek ibadah dan tindakannya sehari-hari.[82]

Dalam Islam, manusia nampak sebagi makhluk yang mempunyai keistimewaan karena dipilih Tuhan sebagai wakil-Nya di dunia, firman Allah dalam surat al-Baqarah ayat 30:

ऽIngatlah ketika Tuhanmu berfirman kepada para malaikat: Sesungguhnya Aku hendak menjadikan seorang khalifah di muka bumi." mereka berkata: "Mengapa Engkau hendak menjadikan (khalifah) di bumi itu orang yang akan membuat kerusakan padanya dan menumpahkan darah, padahal kami senantiasa bertasbih dengan memuji Engkau dan mensucikan Engkau?" Tuhan berfirman: "Sesungguhnya Aku mengetahui apa yang tidak kamu ketahui.

Manusia juga mempunyai kemampuan yang khusus dalam kondisinya yang asli dan tinggi. Sebagaimana disebutkan dalam al-Qur'an surat al-Fussilat ayat 41: 
Sesungguhnya orang-orang yang mengingkari Al Quran ketika Al Quran itu datang kepada mereka, (mereka itu pasti akan celaka), dan Sesungguhnya Al Quran itu adalah Kitab yang mulia.

Begitu juga konsepsi tentang Tuhan, yang berbeda antara konsep Islam dengan konsep-konsep Masehi. Dalam agama Masehi, manusia yang sesudah dibaptiskan adalah merupakan putra Tuhan, dapat berusaha untuk mengambil bagian dalam kehidupan Tuhan itu sendiri berkat daya baru yang telah berkembang di dalam dirinya. Orang Muslim tidak berani sama sekali untuk menggambarkan sesuatu macam partisipasi dalam kehidupan Tuhan, karena orang Muslim tahu benar akan sifat-sifat transenden (mengatasi alam dunia) dari Tuhan.[83]

Seorang Masehi, karena rahasia inkarnasi, dapat mengharap mencapai kebahagiaan abadi dengan jalan bersatu dengan rasa cinta dan kesucian Ilahi dan dengan asimilasi dengan Tuhan sendiri. Hal semacam itu tak terdapatkan bagi seorang Muslim, karena sifat dan sumbernya adalah pembacaan al-Qur'an dan renungan tentang arti kata-kata dalam al-Qur'an. Sifat-sifat Tuhan menjadi penting karena menunjukkan bagaimana seorang Mukmin berusaha memperoleh semacam konsep tentang Tuhan. Walaupun begitu, teologi Islam sangat berhatihati agar jangan terlalu mendalam dalam pemikiran ini; karena khawatir akan merubah sifat Kesatuan (Tauhid) dan transendensi Tuhan sehingga terjerumus kepada antropomorfisme (tasybih) dan polyteisme (syirik).[84]

Sedangkan bagi suatu agama yang mempunyai konsep tentang alam akhirat (eskatologi) seperti Islam, Tuhan adalah satu-satunya referensi yang pokok dan dasar, oleh karena Ia sekaligus adalah asal dan tujuan dari nasib manusia. Oleh karena itu maka perlu rasanya untuk mengetahui gambaran manusia yang telah disajikan oleh fikiran-fikiran Islam, dan gambaran tersebut akan memungkinkan kita memperoleh faham tentang esensi manusia.[85] Islam adalah agama keimanan dan berfikir. Kekuatan ajarannya yang meyakinkan timbul karena ia meneropong realitas dari Zat yang Mutlak dan menunjukkan kesatuan yang harmonis dari penciptaan-Nya yang bersandar Kepada-Nya. Dengan begitu maka Tuhan itu adalah Mutlak dan Maha Kuasa, mempunyai kemauan dan kekuatan. Ia adalah Zat yang paling tinggi dan abstraksi dan berbeda dari segala benda.[86]

Selanjutnya dalam mengkaji masalah manusia, Marcel A. Boisard berpendapat ada tiga macam pendekatan jika ingin mempelajari manusia dalam kedua keadaan (keadaan yang tetap dan keadaan yang berubah) di antaranya:

Pertama, orang dapat menyelidiki manusia dalam hakekatnya yang murni dan esensial. Pendekatan ini adalah yang dilakukan oleh para filosof.

Kedua, orang dapat melakukan penyelidikan dengan mencurahkan segala perhatiaanya kepada prinsip-prinsip ideologis dan spiritual yang mengatur tindakan manusia dan yang mempengaruhi membentuk personalitasnya. Ini adalah pendekatan yang dilakukan oleh para ahli moral dan ahli sosiologi.

Ketiga, dengan mengambil konsep tentang manusia dari penyelidikanpenyelidikan tentang lembaga-lembaga etika dan yuridis yang telah terbentuk dari pengalaman-pengalaman sejarah dan kemasyarakatan, dan yang dihormati oleh karena lembaga-lembaga tersebut telah dapat melindungi perorangan dan masyarakat dengan menerangkan hak-hak dan kewajiban-kewajiban timbal balik antar manusia. Pendekatan ini adalah pendekatan yang dilakukan oleh ahli-ahli hukum dan juga ahli-ahli sejarah. Dalam penyelidikan ini manusia dipelajari dari segi individual, kemudian dari segi kolektif, bukan dalam arti berlakunya hubungan perorangan akan tetapi organisasi masyarakat.[87] 
Dalam al-Qur'an tidak ada suatu subyek yang lebih banyak dibicarakan daripada manusia. Adanya suatu jiwa yang immaterial, yang kekal dan menuju kepada kebahagiaan adalah suatu hal yang pokok (essensial) dalam arti yang sepenuhnya. Jiwa merupakan essensi manusia dalam perspektif nasibnya di kemudian hari. Jiwa harus difahami sebagai suatu realitas yang memang sudah ada yang tak dapat dimengerti dan tak dapat diterangkan. Allah berfirman dalam surat al-Isra ayat 85:

Dan mereka bertanya kepadamu tentang roh. Katakanlah: Roh itu termasuk urusan Tuhan-ku, dan tidaklah kamu diberi pengetahuan melainkan sedikit.[88]

Manusia diciptakan dalam keadaan lemah, firman Allah dalam surat al-Nisa ayat 28:

Allah hendak memberikan keringanan kepadamu, dan manusia dijadikan bersifat lemah.

Dan dalam bentuk yang paling indah, surat al-Tien ayat 4:

令Sesungguhnya kami Telah menciptakan manusia dalam bentuk yang sebaik-baiknya.

Agar ia dapat mempertahankan kedudukannya dan memenuhi kewajibannya dalam sistem yang universal. Dari hikayat penciptaan Adam, bapak manusia, indikasi dan deduksi menjadikan kita dapat lebih memahami watak manusia. Diciptakan langsung dengan tangan Tuhan, manusia berasal dari tanah liat dan diberi ruh yang ditiupkan di dalamnya. Surat Sad ayat 71-72:

(Ingatlah) ketika Tuhanmu berfirman kepada malaikat: "Sesungguhnya Aku akan menciptakan manusia dari tanah". Maka apabila Telah Kusempurnakan kejadiannya dan Kutiupkan kepadanya roh (ciptaan)Ku; Maka hendaklah kamu tersungkur dengan bersujud kepadanya".

Dari kiasan (allegori) ini kita dapat memahami ide tentang autonomi pribadi manusia yang terombang-ambing antara wataknya yang spiritual dan transendental dan ingin mencapai kesempurnaan, dan wataknya yang material yang sangat lemah berhadapan dengan bermacam-macam godaan. Tuhan telah mengangkat derajat anak Adam. Surat al-Isra ayat 70:

Dan Sesungguhnya Telah kami muliakan anak-anak Adam, kami angkut mereka di daratan dan di lautan, kami beri mereka rezki dari yang baik-baik dan kami lebihkan mereka dengan kelebihan yang Sempurna atas kebanyakan makhlukyang Telah kami ciptakan.

Ia telah memberinya pengetahuan yang lebih tinggi daripada pengetahuan malaikat, surat al-Baqarah ayat 31-33:

Dan dia mengajarkan kepada Adam nama-nama (benda-benda) seluruhnya, Kemudian mengemukakannya kepada para malaikat lalu berfirman: "Sebutkanlah kepada-Ku nama benda-benda itu jika kamu mamang benar orang-orang yang benar!" Mereka menjawab: "Maha Suci Engkau, tidak ada yang kami ketahui selain dari apa yang Telah Engkau ajarkan kepada Kami; Sesungguhnya Engkaulah yang Maha mengetahui lagi Maha Bijaksana. Allah berfirman: "Hai Adam, beritahukanlah kepada mereka nama-nama benda ini." Maka setelah diberitahukannya kepada mereka nama-nama benda itu, Allah berfirman: "Bukankah sudah Ku katakan kepadamu, bahwa Sesungguhnya 
Aku mengetahui rahasia langit dan bumi dan mengetahui apa yang kamu lahirkan dan apa yang kamu sembunyikan?"

Akan tetapi Tuhan telah menciptakan manusia dari tanah liat; hal ini akan memperingatkannya terhadap rasa kebesaran yang palsu atau kesombongan yang berlebih-lebihan.[89]

Selanjutnya Marcel A. Boisard memberikan penekanan, "bahwa sebagai agama monoteis, Islam memberikan kepada manusia suatu dimensi ganda yang universal, yaitu pertama, mengaitkannya dengan struktur moral ketuhanan, dan kedua, menjanjikan kepadanya suatu hari kemudian yang kekal".[90]

Dengan demikian jelaslah bahwa prinsip Islam tentang ajaran-ajaran kemanusiaan (humanisme) sepert keadilan, kejujuran, solidaritas kemanusiaan dan toleransi, menimbulkan kewajiban bagi tiap anggota masyarakat Islam dan orang perorangan. Prinsip-prinsip tersebut menimbulkan iklim hormat menghormati dan jaga menjaga yang timbal balik, yang merupakan praktek peradaban yang berdasarkan keagamaan.[91]

4. Asas Kebudayaan

Menurut Ki Hadjar, Tamansiswa tidak berarti asal memelihara kebudayaan kebangsaan, tetapi pertama-tama membawa kebudayaan kebangsaan itu kearah kemajuan yang sesuai dengan kecerdasan zaman, kemajuan dunia dan kepentingan hidup rakyat lahir dan batin pada tiap-tiap zaman dan keadaan.[92]

Memperjelas uraian di atas, Ki Hadjar juga mengatakan kebudayaan adalah buah budi manusia yang beradab sekaligus buah perjuangan manusia di dalam pergulatannya dengan dua kekuatan yang selalu melingkupi kehidupannya, yaitu kodrat alam dan realitas kemajuan masyarakat dari tiaptiap bangsa. Kebudayaan suatu bangsa, menurutnya adalah hasil jerih payah yang dilakukan oleh masyarakat dalam menyelenggarakan kehidupan seharihari. Di sini, kebudayaan mengandung unsur kebersamaan dan persatuan, sehingga kedudukannya menjadi lebih kokoh, sebab dirasakan sebagai milik bersama segenap lapisan masyarakat di suatu bangsa.

Sedangkan menurut analisis penulis, kebudayaan dikatakan Islami apabila ia sesuai dengan pesan-pesan dan nilai-nilai yang dilandasi oleh ajaran Islam. Artinya, kebudayaan sebagai manifestasi dari pemikiran, gagasan, nilainilai dan norma bagi seluruh tindakan dan karya manusia tidak dapat lepas dari ajaran Islam. Atas dasar itulah, hakikat kebudayaan Islam adalah perwujudan secara riil dari pemikiran dan tindakan manusia dalam kedudukannya sebagai hamba Allah dan khalifah-Nya. Dengan formulasi lain, kebudayaan Islam adalah aktualisasi konsep hablun minallah wa hablun minannas, serta bisa juga dirumuskan sebagai aktualisasi peribadatan kepada Allah. Suatu kebudayaan dikategorikan bersifat Islami atau tidak dapat dilihat dari pesan-pesan moral atau nilai-nilai kehidupan yang dibawanya. Bahwa cara berpikir dan cara berbuat yang Islami, yang menyatakan diri dalam seluruh aspek kehidupan, baik yang dilakukan oleh individu maupun sekelompok manusia yang membentuk kesatuan sosial dalam suatu ruang dan waktu tertentu, adalah proses menuju terciptanya kebudayaan Islam.

Dengan demikian, perlu penulis garis bawahi, bahwa budaya dalam Islam haruslah berpedoman pada aqidah Islamiyah berlandaskan al-Qur'an dan alSunnah, seandainya budaya itu tidak berdasarkan pada keduanya serta tidak 
menampilkan ruh dari sumber utama ideologi Islam itu, maka budaya itu bisa dikatakan budaya asing.

5. Asas Kodrat Alam

Menurut Ki Hadjar, asas ini berarti bahwa pada hakikatnya manusia itu sebagai mahluk adalah satu dengan kodrat alam ini. Ia tidak bisa lepas dari kehendaknya, tetapi akan mengalami bahagia jika bisa menjatuhkan diri dengan kodrat alam yang mengandung kemajuan itu, kemajuan yang digambarkan sebagai bertumbuhnya tiap-tiap benih sesuatu pohon yang kemudian berkembang menjadi besar dan akhirnya berbuah, dan setelah menyebarkan benih biji yang baru mengakhiri hidupnya dengan keyakinan, bahwa darmanya akan dibawa hidup terus dengan tumbuhnya lagi benih-benih yang disebarkan.[93]

Berdasarkan uraian di atas, Ki Hadjar menegaskan bahwa kodrat alam adalah segala kekuatan dan kekuasaan alam yang mengelilingi dan melingkupinya, bersifat asli dan jelas yang sewaktu-waktu dapat dilihat dan dinyatakan.[94]

Menurut analisa penulis, dari kedua pengertian di atas, dapatlah dikatakan bahwa penerapan asas kodrat alam sebagai salah satu dari konsepsi Pancadarma yang menjadi dasar pendidikan di Tamansiswa, telah memberikan dasar keyakinan adanya kekuatan kodrat alam. Manusia menurut pemahaman kodrat alam ini, sejak asalnya telah memiliki bekal untuk ditumbuh-kembangkan dan dipelihara sebagaimana mestinya, sehingga memperoleh keselamatan dan kebahagiaan lahir batin, baik untuk kepentingan pribadinya maupun untuk kepentingan masyarakat. kodrat alam adalah segala kekuatan dan kekuasaan alam yang mengelilingi dan melingkupinya, bersifat asli dan jelas yang sewaktuwaktu dapat dilihat dan dinyatakan.

Sedangkan jika ditinjau dari sudut pandang pendidikan Islam, apa yang ada dalam Pancadarma yang dikenal sebagai istilah kodrat alam, hal ini identik dengan istilah fitrah. Fitrah intinya adalah kemampuan dasar dan kecenderungan asli yang murni bersifat pembawaan pada setiap individu. Kemampuan bawaan tersebut muncul dalam bentuk yang sederhana dan terbatas sekali, kemudian terjadi proses interaksi dengan lingkungan sehingga tumbuh dan berkembang ke arah yang lebih baik dan sempurna atau bisa pula sebaliknya, tergantung pengaruh yang diterima dari lingkungan tersebut.

Muhammad At-Taumy al-Syaibani menyatakan:

Bahwa fitrah manusia dengan segala potensi yang dimilikinya merupakan conditional statement (hal bersyarat) yang aktualisasinya tergantung pada individu itu sendiri... Islam menegaskan bahwa manusia memiliki fitrah dan sumber insani serta bakatbakat bawaan (keturunan), tetapi semua itu masih merupakan potensi, dalam arti memiliki berbagai kemungkinan. Bagaimanapun juga, faktor keturunan bukanlah suatu faktor yang kaku, dalam arti ia bisa mengalami kelenturan atau bergeser karena pengaruh lingkungan. Maka berarti, lingkungan sekitar adalah faktor pendidikan yang sangat penting.[95]

Melihat keterangan Muhammad At-Taumy al-Syaibani di atas, Islam memandang bahwa pendidikan sebagai proses pertumbuhan tingkah laku baik secara individu maupun kelompok, hanya akan berhasil dengan adanya sesuatu di sekelilingnya di mana ia hidup. 
Akhirnya, Setelah memperhatikan uraian panjang di atas, menurut penulis nampaknya ada persamaan dan perbedaan antara dasar pendidikan Ki Hadjar dengan dasar pendidikan Islam. Persamaannya ditinjau dari sudut pandang pendidikan Islam, sebagian asas dalam konsepsi Pancadarma memiliki relevansi sedemikian rupa. Dalam arti bagian satu dengan lainnya juga merupakan sesuatu yang dianggap penting dan perlu dijadikan tempat dasar berpijak bagi pendidikan. Hanya saja, dalam beberapa hal terdapat perbedaan baik mengenai istilah yang dipakai maupun sumber rujukannya.

Sedangkan perbedaannya menurut hemat penulis nampak pada sumber dasarnya, dimana pendidikan Islam adalah pendidikan yang bersumberkan pada wahyu Ilahiyah berupa al-Qur'an dan al-Sunnah. Abdurrahman al-Nahlawi mengatakan: "Bahwa sumber-sumber pokok pendidikan Islam adalah al-Qur'an dan al-Sunnah".[96]·Hal ini juga dipertegas oleh Wan Mohammmad Wan Daud, mengutip pendapat Syed M. Naquib al-Attas-: "Bahwa pendidikan Islam berdasarkan sumber-sumber yang jelas dan mapan, yang pemahaman, penafsiran dan penjelasannya membutuhkan ilmu pengetahuan yang otoritatif". Lebih lanjut ia mengatakan:

Salah satu aspek penting dalam pendidikan Islam adalah pencarian dan pengakuan otoritatif yang benar dalam setiap cabang ilmu dan pengetahuan, sebuah prinsip yang diikuti dan dipraktekkan oleh al-Attas. Dia mengatakan bahwa otoritas tertinggi adalah al-Qur'an dan Nabi yang diteruskan oleh para sahabat dan para ilmuan lakilaki dan perempuan yang benar-benar mengikuti sunnahnya....[97]

M. Nasir Budiman yang menegaskan: "sesuai tuntunan al-Quran bahwasannya yang menjadi inti pendidikan (intracuriculer) adalah tauhid atau keimanan yang harus dimantapkan dengan unsur pokok yang tidak dapat dirubah". Tauhid merupakan esensi dan inti ajaran Islam serta merupakan nilai dasar dari realitas dan kebenaran yang universal untuk semua tempat dan waktu dari sejarah nasib manusia.[98]

Achmadi juga menyatakan, tauhid adalah landasan bagi seluruh kegiatan hidup dan kehidupan umat manusia termasuk pendidikan, karena dalam pandangan hidup Islam, tauhid merupakan nilai yang paling esensial dan sentral, bahkan seluruh gerak hidup Muslim tertuju ke sana (ghayah al-hayyat). Dengan dasar tauhid seluruh kegiatan pendidikan Islam dijiwai oleh norma-norma Ilahiyah dan sekaligus dimotivasi sebagai ibadah. Dengan ibadah pekerjaan pendidikan lebih bermakna, tidak hanya makna materiil tetapi juga makna spiritual.[99]

Tauhid merupakan fondasi seluruh bangunan ajaran Islam. Pandangan hidup tauhid bukan sekedar pengakuan akan ke-Esa-an Allah Swt, tetapi juga meyakini kesatuan penciptaan (unity of creation), kesatuan kemanusiaan (unity of mankind), kesatuan tuntunan hidup (unity of guidance), dan kesatuan tujuan dari kesatuan ketuhanan (unity of Godhead). Bila pengertian ini ditarik dalam kehidupan sosial maka tauhid tidak mengakui adanya kontradiksi-kontradiksi berdasarkan kelas, keturunan, dan latar belakang geografis.[100]

Akhirnya menurut analisa penulis, dasar pendidikan Ki Hadjar secara eksplisit tidak menampilkan kedua sumber pendidikan Islam itu (al-Qur'an-alSunnah) yang inti ajarannya adalah tauhid (keimanan). Pancadarma Ki Hadjar mendasarkan diri pada kebudayaan nasional Indonesia yang bersumberkan pada nilai-nilai kodrat alam, kemanusiaan, dan keluhuran bangsa. 
D.Analisis Isi Pendidikan Ki Hadjar Perspektif Pendidikan Islam

1. Pendidikan Budi Pekerti

Dalam beberapa buku tulisan Ki Hadjar Dewantara tidak ditemukan istilah karakter jika karakter yang dimaksud itu adalah akhlak dalam Islam, tetapi secara inplisit istilah itu muncul dalam berbagai buku karangannya dengan istilah budi pekerti. Budi pekerti dalam pandangan Ki Hadjar merupakan jiwa atau ruh dari pengajarananya, karena pengajaran dan budi pekerti ibarat dua sisi mata uang yang tidak bisa dipisahkan, hal yang demikian menurutnya karena pengajaran atau pendidikan berarti menuntun tumbuhnya budi pekerti dalam hidup anak didik supaya mereka kelak menjadi manusia berpribadi yang beradab dan susila.[101]

Budi pekerti menurut Ki Hadjar bukan sekedar konsep yang bersifat teoritis sebagaimana yang dipahami oleh masyarakat pada umumnya, bukan pula pengajaran budi pekerti dalam arti mengajar teori tentang baik buruk, benar salah dan seterusnya, bahkan dikiranya pengajaran budi pekerti mengandung arti pemberian kuliah atau ceramah tentang hidup kejiwaan atau peri-keadaban manusia dan atau keharusan memberi keterangan-keterangan tentang budi pekerti secara luas dan mendalam. Budi pekerti yang sebenarnya adalah hendaknya perlu diinsyafi bahwa pengajaran budi pekerti tidak lain adalah untuk menyokong perkembangan hidup anak-anak lahir dan batin dari sifat kodratinya menuju ke arah peradaban dalam sifatnya yang umum, seperti memerintahkan anak untuk duduk yang baik, jangan berteriak-teriak agar tidak mengganggu orang lain, bersih badan dan pakaian, hormat terhadap ibu bapak dan orang lain, menolong dan lain sebagainya.[102]

Ki Hadjar yang sangat konsen dengan dunia pendidikan mengharapkan kepada anak-anak didik hendaknya diberikan anjuran-anjuran untuk melakukan pelbagai laku yang baik dengan cara disengaja. Dengan begitu maka syarat pendidikan budi pekerti yang dahulu biasa saja disebut metode menyadari, menginsyafi dan melakukan, atau ngerti, ngerasa dan ngelakoni (tri-nga) dapat terpenuhi.[103]

Gambaran di atas jelas memperlihatkan perhatian Ki Hadjar terhadap pentingnya pendidikan budi pekerti yang ditekankan pada pembentukan karakter, perilaku dan kepribadian melalui upaya pembiasaan melakukan perbuatan terpuji yang dilakukan mulai dari sejak kecil hingga dewasa. Pendidikan budi pekerti yang dimaksudkan olehnya bukanlah mengajarkan teoriteori tentang baik buruk dengan dalil-dalinya yang serba menjelimet. Yang ia kehendaki dengan pendidikan budi pekerti adalah pembiasaan berbuat baik pada diri anak dalam kehidupan sehari-hari, hingga mendarah daging, kalaupun ada penjelasan dan keterangan hal yang demikian dilakukan hanya sebagi penguat dan alat, bukan tujuan.

Ki Hadjar menghendaki budi pekerti yang bersifat integrated dengan pengajaran pada setiap bidang studi. Dengan kata lain, Ki Hadjar menginginkan bahwa pada setiap pengajaran bidang studi apapun harus mengintegrasikannya dengan pendidikan budi pekerti, dan tidak berhenti pada pengajaran mata pelajaran tersebut semata-mata. Baginya pengajaran adalah alat bukan tujuan. Pengajaran matematika misalnya adalah alat untuk menghasilkan anak yang memiliki keterampilan dalam memahami dan mempraktikkan rumusan hitungan secara tepat dan akurat. Namun bersamaan dengan itu pengajaran matematika 
tersebut harus diarahkan pada menghasilkan manusia yang dapat bersikap teliti, cermat, kerja teratur dan jujur.[104]

Budi pekerti dalam implementasi di Tamansiswa Yogyakarta adalah bertujuan agar anak-anak didik dapat kemajuan alam hidupnya lahir dan batin menuju ke arah adab kemanusiaan. Budi pekerti di sini juga tidak hanya menghendaki pembentukan intelek, tetapi menghendaki juga pendidikan dalam arti pemeliharaan dan pelatihan susila (budi), karena menurut Ki Hadjar, adab atau keluhuran budi manusia itu menunjukkan sifat batinnya manusia, sedangkan kesusilaan atau kehalusan itu menunjukkan sifat hidup lahiriyah manusia yang serba halus dan indah. Sebagaimana pernyataannya, "bahwa budi pekerti seseorang itu dapat mewujudkan sifat batinnya seseorang dengan pasti dan tetap". Ki Hadjar juga menegaskan "bahwa tidak ada dua budi pekerti orang yang sama, meskipun sama dua roman wajah seseorang, tidaklah sama kedua budi pekertinya".[105]

Ki Hadjar juga berpendapat bahwa pendidikan budi pekerti harus mempergunakan syarat-syarat yang selaras dengan jiwa kebangsaan menuju kepada kesucian, ketertiban dan kedamaian lahir batin. Dengan demikian melihat gagasan dan pemikirannya tentang pendidikan budi pekerti di atas, terlihat dengan jelas diarahkan pada pembentukan karakter bangsa yang sesuai dengan nilai-nilai budaya bangsa yang universal.[106]

Sementara Islam meletakkan sifat-sifat baik seperti: jujur, sopan dan toleransi semuanya dalam bingkai dan dasar keimanan, bukan sekedar "rasa kemanusiaan" semata yang lepas dari nilai-nilai Islam. Seorang muslim diajarkan untuk jujur, bukan karena kemanfaatan sifat jujur semata, tetapi karena jujur itu perintah Allah Swt. Sebagaimana diungkapkan Adian Husaini, bahwa semua aktifitas kemanusiaan baik berupa amal shaleh, akhlak, maupun nilai-nilai kebajikan lainnya seperti jujur, kebersihan, dan kerja keras, harus dilandasi dan dalam bingkai keimanan, jika amal shaleh atau sifat kemanusiaan yang tidak dilandasi dengan keimanan maka perbuatan itu akan menjadi berbahaya bahkan melanggar batas-batas ketentuan Allah Swt".[107]

Dan hubungan antara iman dan budi pekerti adalah hubungan yang tidak bisa dilepaskan, karena iman merupakan sumber akhlak yang luhur, akhlak pada gilirannya menuntun manusia untuk menemukan kebenaran dan hakikat sesuatu, sedangkan ilmu akan menuntun manusia untuk menjadi manusia yang beradab. Hal ini sejalan dengan misi kerasulan Nabi Muhammad Saw. yaitu untuk menyempurnakan akhlak yang mulia.[108]

Jadi dalam pandangan Islam ternyata pemikiran Ki Hadjar tentang budi pekerti ini tidak sesuai dengan ajaran Islam, karena dalam Islam dinyatakan bahwa semua aktifitas kehidupan harus berlandaskan pada tauhid atau keimanan, karena keimanan merupakan soko-guru utama dalam Islam. Dan semua aktifitas yang berpijak pada dasar keimanan akan mendatangkan hasil yang lebih berkualitas lahir maupun bathin, lantaran iman merupakan hubungan antara hamba dan Sang Khaliq.[109]

Muhaimin menambahi, bahwa iman merupakan potensi rohani yang harus diaktualisasikan dalam bentuk amal sholeh, sehingga menghasilkan prestasi rohani yang disebut takwa.[110]

Dengan demikian, menurut analisis penulis bahwa gagasan Ki Hadjar tentang budi pekerti ini tidak ditemukan landasan yang bertalian erat dengan tauhid, melainkan berpijak pada kepribadian bangsa yang universal, hal ini dapat ditemui 
bahwa Ki Hadjar menginginkan agar bangsa Indonesia memiliki sikap dan pandangan yang maju dan tetap berpijak pada kepribadian bangsa Indonesia yang memiliki budaya dan kepribadian yang khas. Untuk itu penulis menyarankan agar konsep-konsep Ki Hadjar tentang budi pekerti yang bersifat universal ini dimasukkan unsur-unsur ke-tauhid-an dan mengembangkan konsepnya dengan berbasiskan iman dan takwa (imtak) agar berjalan sesuai UU Sisdiknas No 20 Pasal 3 tahun 2003.

\section{Pendidikan Kemanusiaan (Humanisme)}

Menurut Ki Hadjar pendidikan kemanusiaan ini mempunyai arti bahwa darma tiap-tiap manusia itu adalah mewujudkan kemanusiaan, yang berarti kemajuan kemanusiaan lahir dan batin yang setinggi-tingginya, dan kemajuan manusia yang tinggi itu dapat dilihat pada kesucian hati orang dan adanya rasa cinta kasih terhadap sesama manusia dan terhadap mahluk Tuhan seluruhnya, tetapi cinta kasih yang tidak bersifat kelembekan hati, melainkan bersifat keyakinan adanya hukum kemajuan yang meliputi alam semesta. Karena itu dasar cinta kasih kemanusiaan itu harus tampak pula sebagai kesimpulan untuk berjuang melawan segala sesuatu yang merintangi kemajuan selaras dengan kehendak alam.[111]

Dengan adanya kemanusiaan ini, Ki Hadjar berpedoman bahwa intisari dari pendidikan (dalam arti yang sesungguhnya) adalah proses memanusiakan manusia (humanisasi), yakni pengangkatan manusia ke taraf insani. Di dalam mendidik ada pembelajaran yang merupakan komunikasi eksistensi manusiawi yang otentik kepada manusia, untuk dimiliki, dilanjutkan dan disempurnakan. Jadi sesungguhnya pendidikan adalah usaha bangsa ini membawa manusia Indonesia keluar dari kebodohan, dengan membuka tabir aktual-transenden dari sifat alami manusia.[112]

Berdasarkan uraian di atas, nampak jelas bahwa Ki Hadjar dalam hal kemanusiaan berkesimpulan agar sifat kemanusiaan itu bisa berjuang melawan segala sesuatu yang dapat merintangi kemajuan yang selaras dengan kehendak alam.

Sementara dalam pendidikan Islam, Islam memiliki pandangan sedemikian rupa tentang manusia dan berbagai ikhwal kemanusiaannya, diantaranya pandangan yang dikemukakan oleh Asy-Syaibani, menurutnya: 1) manusia adalah makhluk termulia dari segenap makhluk dan wujud lain di alam ini, 2) manusia diberi amanah atau taklif untuk menjadi khalifah Allah di bumi, 3) manusia sebagai makhluk sosial yang dapat berbahasa sebagai media komunikasi dan berpikir, 4) manusia dengan perwatakannya yang asli dan ciri pertumbuhannya adalah hasil pencapaian dua faktor: warisan dan lingkungan, 5) manusia memiliki motivasi, kecenderungan dan keputusan untuk berbuat sesuatu baik yang diwarisi maupun diperolehnya melalui proses sosialisasi, 6) bahwasanya manusia itu satu dengan yang lain berbeda dalam hal bakat dan kemauan, antara lain karena perbedaan dari segi keturunan dan lingkungan, dan 7) manusia memunyai keluwesan sifat yang dapat dibentuk dan diubah melalui pendidikan.

Sedangkan menurut Sholehan, bahwa implikasi terpenting yang berhubungan dengan pendidikan, khususnya berkaitan dengan prinsip dasar pandangan Islam terhadap manusia adalah: 1) sejauh mana manusia dipandang sebagai khalifah Allah di bumi, maka konsekuensinya harus memperhatikan pertumbuhan 
serta perkembangan individu secara harmonis agar individu tersebut mampu mengatasi tantangan alam dan lingkungannya, 2) adanya konsep fitrah, mengharuskan pendidikan Islam bertujuan untuk membimbing dan mengarahkan potensi dasar manusia ke arah yang baik dan benar, dan 3) pelaksanaan pendidikan harus memerhatikan kondisi dan karakter anak didik serta faktor lingkungannya, demikian juga waktu yang tepat untuk melangsungkan kegiatan belajar mengajar.[113]

Dengan demikian jelaslah bahwa prinsip Islam tentang ajaran-ajaran kemanusiaan (humanisme) sepert keadilan, kejujuran, solidaritas kemanusiaan dan toleransi, menimbulkan kewajiban bagi tiap anggota masyarakat Islam dan orang perorangan. Prinsip-prinsip tersebut menimbulkan iklim hormat menghormati dan jaga menjaga yang timbal balik, yang merupakan praktek peradaban yang berdasarkan agamaan dan tauhid.

3. Pendidikan Kebebasan (Kemerdekaan)

Pendidikan kebebasan yang harapkan Ki Hadjar mengandung maksud bahwa Tamansiswa tidak boleh bertentangan dengan asas kemerdekaaan. Sebagaimana gambaran Ki Hadjar yang menghendaki bahwa kemerdekaan adalah kodrat alam kepada semua mahluk manusia yang memberikan kepadanya hak "swa-wasesa" dengan selalu mengingati syarat-syarat tertib damainya hidup bersama. kemerdekaan di sini harus diartikan "swa-disiplin" atas dasar nilai hidup yang tinggi, baik hidup sebagai individu maupun sebagai anggota masyarakat. Kemerdekaan harus juga menjadi dasar untuk mengembangkan pribadi yang kuat dan sadar dalam suasana perimbangan dan keselarasan dengan masyarakatnya.[114]

Melihat uraian di atas, terlihat jelas bahwa kemerdekaan dalam penyelenggaraan pendidikan Ki Hadjar berarti memberikan kebebasan yang profesional kepada anak didik dalam berpikir dan berbuat untuk mencapai citacitanya, itulah sebabnya tujuan pendidikan Tamansiswa adalah mengembangkan dan membangun orang yang dapat berpikir dan berbuat secara merdeka, lahir dan batin. Maka dalam pendidikan harus senantiasa diingat bahwa kemerdekaan itu sifatnya berdiri sendiri, dapat mengatur diri sendiri, dan tidak bergantung kepada orang lain.

Menurut penulis, jika dilihat dari sudut pendidikan umum, maka asas kemerdekaan yang terdapat dalam Pancadarma sesungguhnya merupakan sesuatu yang pantas untuk diambil manfaatnya bagi kepentingan anak didik dalam arti yang luas, karena pada prinsipnya aktifitas pendidikan juga memberikan tempat utama terhadap prinsip-prinsip dasar kemerdekaan manusia.

Sedangkan menurut Sholehan, seorang peneliti dasar pendidikan Ki Hadjar sekaligus dosen IAIN Ampel Surabaya, bahwa ajaran Islam memandang kemerdekaan sebagai hal yang bersifat natural pada manusia, tanpa kebebasan maupun kemerdekaan manusia tidak dapat diharapkan memiliki tanggung jawab atas segala perbuatannya. Seseorang dianggap bermoral, apabila dapat berbuat sesuai dengan kebebasannya, karena dari sinilah nilai moral itu berarti. Menurut ajaran Islam, setiap manusia itu dijamin kemerdekaannya sebagai sesuatu yang mendasar dan asasi. Realitas kemerdekaan yang dimiliki manusia adalah wujud dari jaminan agama Islam atas kebebasan yang bersangkutan untuk berkemauan sendiri, di mana apabila kemerdekaan tersebut terganggu, maka berarti ancaman bagi eksistensi dirinya.[115] 
Sementara Hasan Langgulung mengatakan, prinsip-prinsip yang merupakan pandangan Islam tentang kebebasan dan kemerdekaan manusia adalah sebagai berikut: 1) menekankan hubungan dan keseimbangan antara prinsip kebebasan, persaudaraan, dan persamaan, 2) menekankan kebebasan dan lemah lembut, toleransi, persaudaraan, dan kasih sayang. Tetapi dengan tegas harus diatur oleh hukum, 3) menekankan kebebasan yang menyelaraskan antara kedudukan individu dan masyarakat dalam memeroleh hak masing-masing dan didorong serta dilandasi oleh akhlak dengan memperhatikan harga diri manusia, 4) kebebasan yang menyelaraskan hubungan individu dan masyarakat dengan memperhatikan unsur kemaslahatan dan hak memperoleh perlindungan hidup bersama, 5) menjamin terpenuhinya kebebasan individu dalam kehidupan sehari-hari dengan syarat tidak mengganggu ketertiban dan aturan masyarakat, dan 6) melaksanakan kebebasan dalam kerangka agama, akhlakul karimah, tanggung jawab, akal sehat, dan keindahan.[116]

Imam Zarkasyi, seorang tokoh dan pendiri Pondok Pesantren Modern Gontor dalam buku A. Susanto, Pemikiran Pendidikan Islam, Jakarta: Amzah, 2009, hlm. 145) menyatakan, pola pikir dan kebebasan yang diterapkan di pesantren ini dilakukan dengan cara pembiasaan, keteladanan, dan pengondisian lingkungan, hal ini dimaksudkan untuk menanamankan jiwa bebas, merdeka, berkepribadian, dan berkeyakinan hidup.[117]

Imam Zarkasyi juga menegaskan, yang dimaksud dengan pola pikir bebas dan merdeka di sini adalah kebebasan yang berada dalam garis-garis disiplin yang positif dengan penuh tanggung jawab, baik dalam kehidupan pondok maupun di masyarakat. Kebebasan ini juga menghendaki santri yang memiliki jiwa berdiri di atas kaki sendiri atau berdikari. Santri bebas untuk menentukan masa depannya dengan memiliki jiwa keikhlasan dan jiwa kesedernaan dalam hidup.[118]

Sedangkan menurut Marcel A. Boisard, bahwa kemerdekaan manusia berada dalam memilih secara berfikir untuk menghormati hukum-hukum yang diwahyukan dan mengetahui perintah-perintah Tuhan. Memilih pilihan yang bersandar kepada fikiran. Pertangjawaban pribadi yang akan dihadapi tiap orang di hari kiamat mengandung arti bahwa manusia itu diberi kemampuan untuk memilih, jadi diberi kemerdekaan. Di sinilah letak kebesaran manusia. Allah Swt berfirman dalam surat al-Tahrim ayat 7:

Hai orang-orang kafir, janganlah kamu mengemukakan uzur pada hari

ini. Sesungguhnya kamu Hanya diberi balasan menurut apa yang kamu kerjakan.[119]

Melihat uraian di atas Marcel A. Boisard berpendapat bahwa manusia itu merdeka. Kalau kita ingkar akan kemerdekaan manusia, ini berarti bahwa kita mengatakan bahwa Tuhan itu tidak adil karena dia menyiksa atau memberi pahala kepada manusia atas dasar bahwa manusia itu tidak merdeka memilih sesuatu, yakni bahwa ia itu tidak bertanggungjawab.[120] Tuhan sendiri adalah kemerdekaan yang mutlak, akan tetapi kemerdekaan manusia itu walaupun hanya relatif, juga tetap merupakan kemerdekaan, sebagaimana cahaya yang lemah juga merupakan cahaya. Karena manusia tidak mengetahui kehidupan yang akan datang yang disediakan oleh Tuhan baginya maka tindakan-tindakannya timbul dari keputusan yang diambil oleh kemauannya dan kepandaiannya. Jadi manusia itu merdeka dan bertanggungjawab tentang pilihannya.[121] 
Akhirnya penulis menyimpulkan, bahwa kebebasan manusia tidaklah mutlak sifatnya, sebab ia terikat oleh tanggung jawab moral untuk dirinya sendiri dan kepentingan masyarakat luas. Kemerdekaan yang hakiki adalah jika seseorang dapat menundukkan hawa nafsu dan mampu menguasai ajakan hati yang sekiranya dapat menjerumuskan ke arah jalan hidup yang menyimpang. Kemerdekaan adalah konsep yuridis sedemikian rupa yang didasari oleh ketentuan Allah, bukan sekedar atas dasar nilai moral manusia. Konsekuensinya, semua perbuatan manusia termasuk bagaimana ia menghormati kemerdekaan orang lain, sesungguhnya merupakan ekspresi semata dari ketundukan manusia terhadap Allah Swt.

4. Pendidikan Spiritual

Menurut Ki Hadjar, pada hakikatnya manusia itu adalah satu dengan kodrat alam semesta ini. Karena itu manusia tidak bisa lepas dari kehendak hukumhukum kodrat alam. Manusia akan mengalami kebahagiaan, jika ia dapat mesra menjatuhkan diri dengan kodrat alam yang mengandung segala hukum kemajuan. Kemajuan yang dapat digambarkan sebagai bertumbuhnya tiap-tiap benih sesuatu pohon yang kemudian berkembang menjadi besar dan akhirnya berbuah, dan setelah menyebarkan benih biji yang baru mengakhiri hidupnya dengan keyakinan, bahwa darmanya akan dibawa hidup terus dengan tumbuhnya lagi benih-benih yang disebarkan.[122]

Ki Hadjar juga menegaskan bahwa inti dari pendidikan dan pengajaran yang terluhur adalah terkandung dalam kodrat alam. Untuk mengetahui kodrat alam itu perlulah orang mempunyai wijsheid (bersihnya budi), yang harus terdapat dari tajamnya angan-angan, halusnya rasa, dan suci-kuatnya kemauan, yaitu sempurnanya cipta-rasa-karsa.[123]

Melihat uraian di atas, terlihat jelas bahwa maksud dari pendidikan Ki Hadjar adalah untuk sempurnanya hidup manusia, hingga dapat memenuhi segala keperluan hidup lahir dan batin yang di dapat dari kodrat alam.

Sedangkan dalam pendidikan Islam, ia memiliki kriteria-kriteria yang berbeda dengan konsep pendidikan Ki Hadjar, dimana pendidikan Islam yang memperhatikan kedua kehidupan, yaitu dunia dan akherat secara nyata mengandung empat unsur yang harus di aplikasikan secara bersama-sama, yaitu keimanan, amaliah (aplikatif), ilmiah, akhlak, dan sosial. Sedangkan isi pendidikan yang ditawarkan Ki Hadjar secara nyata mengandung unsur kebebasan (merde$k a$ ), kemanusiaan (humanisme), spiritual (kodrat alam), budi pekerti, sosial (kekeluargaan) dan demokrasi (tut wuri handayani) terindikasi sepi dari nilai-nilai keimanan dan ketauhidan.

Tauhid merupakan inti sari pendidikan dan pondasi dari segala ajaran dalam Islam, sedangkan keimanan merupakan soko-guru utamanya, dimana sistem pendidikan yang berpijak pada dasar keimanan akan mendatangkan hasil yang lebih berkualitas lahir maupun bathin, sebab iman merupakan hubungan antara hamba dan Sang Khaliq.[124] Sebagaimana firman Allah Swt dalam Surat al-Baqarah ayat 285:

Rasul telah beriman kepada al-Qur'an yang diturunkan kepadanya dari Tuhannya, demikian pula orang-orang yang beriman. Semuanya beriman kepada Allah, malaikat-malaikat-Nya, kitab-kitab-Nya dan rasul-rasul-Nya. (mereka mengatakan): "Kami tidak membeda-bedakan antara seseorangpun (dengan yang lain) dari rasul-rasul-Nya", dan mereka mengatakan: "Kami dengar dan 
kami taat". (mereka berdo'a): "Ampunilah kami ya Tuhan kami dan kepada Engkaulah tempat kembali".

Iman merupakan sumber akhlak yang luhur; akhlak pada gilirannya akan menuntun manusia untuk menemukan kebenaran dan hakikat sesuatu, sedangkan ilmu akan menuntun manusia untuk mengerjakan amal shaleh. Iman juga merupakan potensi rohani yang harus diaktualisasikan dalam bentuk amal sholeh, sehingga menghasilkan prestasi rohani yang disebut takwa.

Mengenai keimanan, Adian Husaini mengatakan: "jika amal shaleh atau sifat kemanusiaan yang tidak dilandasi dengan keimanan maka perbuatan itu akan menjadi berbahaya, bahkan melanggar batas-batas ketentuan Allah Swt".[125]

Islam sangat menghargai nilai-nilai humanisme, kebebasan, budi pekerti, kebaikan, kejujuran, kebersihan, kerja keras, dan sebagainya. Akan tetapi jika nilai-nilai kebaikan itu tidak dilandasi keimanan, maka hal itu menjadi rapuh dan hampa, hanya kemanusiaan belaka.

Rasulullah Saw misalnya, menganjurkan dan menekankan sifat kejujuran, karena kejujuran akan mengantarkan seseorang ke surga. Rasulullah Saw juga mengajarkan do'a, agar umatnya dijauhkan dari sifat lemah dan malas, dan ajaran-ajaran mulia lainnya. Akan tetapi, Islam meletakkan sifat-sifat mulia tersebut dalam bingkai dan dasar keimanan. Bukan sekedar "rasa kemanusiaan" semata, yang lepas dari nilai-nilai Islam. Seorang muslim diajarkan untuk jujur, bukan karena kemanfaatan sifat jujur semata, tetapi karena jujur itu perintah Allah Swt.[126]

Sedangkan isi pendidikan dalam pendidikan Ki Hadjar, menurut penulis tidak menampilkan ruh keimanan yang sesungguhnya. Keimanan (spiritual) menurutnya adalah suatu kehendak alam (kodrat alam).

Selain tidak adanya pendidikan keimanan, Ki Hadjar juga dianggap mempunyai paham kejawen dan kebatinan, sebagaimana diungkapkan Hamka sebelumnya. Meskipun dalam hal ini, (yakni paham ajaran abangan, klenik dan primbon Jawa) dibantah oleh Ki Agus Purwanto, anggota Majlis Luhur Persatuan Tamansiswa. Menurutnya bahwa Ki Hadjar adalah seorang tokoh beragama Islam, yang hidup dalam lingkungan keraton Jawa, sehingga berbagai konsep yang digagasnya banyak menggunakan istilah Jawa.[127]

Hal ini dipertegas oleh Ki Priyo Dwiarso, anggota Majelis Luhur Persatuan Tamansiswa yang menyatakan, bahwa konsep pendidikan yang digagas Ki Hadjar bukanlah kejawen. Memang konsep budaya dan pendidikan Ki Hadjar Dewantara banyak mempergunakan istilah bahasa Jawa, sehingga ada yang mengatakan dengan "dangkal" bahwa konsep Ki Hadjar berbasis Kejawen. Istilah "kejawen" dalam konteks ini bisa merugikan karena berkonotasi negatif sempit. Memang ajaran Ki Hadjar banyak menggunakan istilah bahasa Jawa misalnya "tut wuri handayani", "wiyata griya", "sistema among", "ngerti-ngroso-nglakoni". Bahkan sarasehan Rebo Wagen lebih memperberat konotasi negatif tersebut. Padahal Rebo Wagen diambil Ki Hadjar dari hari kelahiran Pangeran Diponegoro agar dapat mewarisi api juangnya.[128]

Ki Priyo, menegaskan, bahwa Ki Hadjar mempergunakan istilah dengan bahasa Jawa dengan dua alasan yang reasenable yaitu:

Pertama, Ki Hadjar konsisten dengan konsentrisitas budaya. Budaya (ilmu) universal yang didapat diterapkan dalam praktisi budaya nusantara secara konsentris, yaitu tidak meninggalkan "local wisdom" budaya sendiri. 
Kedua, yaitu pada zaman Ki Hadjar (1922) belum ada Sumpah Pemuda dengan lingua franca bahasa Indonesia. Sehingga konsentrisitas budaya tersebut "terpaksa" mempergunakan istilah bahasa Jawa.[129]

Dengan demikian, setalah penulis uraiakan panjang lebar tentang analisis isi pendidikan Ki Hadjar Dewantara dalam pandangan pendidikan Islam. Berikut penulis ringkaskan lewat sebuah tabel agar mudah dipahami.

E.Analisis Sistem Pendidikan Ki Hadjar Perspektif Pendidikan Islam

Pada bab sebelumnya sudah dijelaskan bahwa ditinjau dari sistemnya, pendidikan adalah suatu kegiatan yang di dalamnya mengandung aspek tujuan, kurikulum, metode, guru, murid, dan evaluasi, yang antara satu dan lainnya saling berkaitan dan membentuk suatu sistem yang terpadu.

1. Tujuan Pendidikan

Dalam bab IV diterangkan bahwa tujuan pendidikan menurut Ki Hadjar adalah bertujuan untuk mengangkat harkat, martabat dan kemajuan umat manusia secara universal, sehingga mereka dapat berdiri kokoh sejajar dengan bangsa-bangsa lain yang telah maju dengan tetap berpijak kepada identitas dirinya sebagai bangsa yang memiliki peradaban dan kebudayaan yang berbeda dengan bangsa lain.

Tujuan lain dari didirikannya perguruan Tamansiswa adalah sebagai lembaga pendidikan dan kebudayaan untuk terwujudnya masyarakat tertib dan damai, sedangkan tertib sebagaimana konsep Ki Hadjar tidak akan ada jika tidak ada damai antar manusia; damai antar manusia itu hanya mungkin ada dalam keadilan sosial sebagai wujud berlakunya kedaulatan adab kemanusiaan yang menghilangkan segala rintangan oleh manusia terhadap sesamanya dalam saratsarat hidupnya, serta menjamin terbaginya sarat hidup lahir batin secara samarata sama-rasa.

Sedangkan tujuan pendidikan Islam sebagaimana dijelaskan pada bab II bahwa pendidikan Islam bertujuan untuk merealisasikan manusia muslim yang beriman dan bertaqwa serta berilmu pengetahuan yang mampu mengabdikan dirinya kepada Khalik-nya dengan sikap dan kepribadian bulat yang menunjuk kepada penyerahan diri kepada-Nya dalam segala aspek hidupnya, duniawiyah dan ukhrawiyah.

Tujuan lain dari pendidikan Islam ialah untuk melahirkan manusia yang shaleh, selamat dan bahagia di dunia dan akhirat, adapun tujuan lain yang sifatnya duniawi seperti mencari pekerjaan, uang atau jabatan adalah ilusi dan sia-sia belaka. Sebagaimana diungkapkan al-Ghazali yang dikutip oleh Syamsuddin Arif: "Sesungguhnya tujuan dari pendidikan ialah untuk mendekatkan diri pada Allah 'Azza wa Jalla, bukan pangkat dan bermegahmegahan".[130]

Sedangkan tujuan pendidikan nasional sebagaimana dalam UU No. 20 tahun 2003 tentang Sistem Pendidikan Nasional, Pasal 3, disebutkan:

Pendidikan nasional berfungsi mengembangkan kemampuan dan membentuk watak serta peradaban bangsa yang bermartabat dalam rangka mencerdaskan kehidupan bangsa, bertujuan untuk berkembangnya potensi peserta didik agar menjadi manusia yang beriman dan bertakwa kepada Tuhan Yang Maha Esa, berakhlak mulia, sehat, berilmu, cakap, kreatif, mandiri, dan menjadi warga negara yang demokratis serta bertanggung jawab.[131] 
Memperhatikan kedua uraian di atas, menurut analisis penulis terdapat beberapa hal yang sangat mendasar ketidak sesuaian antara tujuan pendidikan Ki Hadjar dengan tujuan pendidikan Islam. Ketidak sesuaian itu, terletak pada pembentukan manusia yang beriman dan bertauhid. Hal ini bisa dilihat dari tujuan pendidikan Ki Hadjar yang tidak menampilkan kedua fungsi tersebut, yaitu keimanan dan tauhid. Ki Hadjar hanya merumuskan bahwa tujuan pendidikan adalah untuk mengangkat harkat, martabat dan kemajuan umat manusia secara universal, sehingga mereka dapat berdiri kokoh sejajar dengan bangsa-bangsa lain yang telah maju. Sekali lagi, tidak ada unsur keimanan dan tauhid yang ditonjolkan dalam tujaun pendidikannya.

Berbeda dengan pendidikan Islam, dimana pendidikan Islam selain untuk mengangkat harkat dan martabat manusia serta terwujudnya masyarakat tertib dan damai, pendidikan Islam juga sangat mengedepankan unsur-unsur taudid dan ibadah (ta'abbudi), karena kedua unsur ini adalah esensi diciptakannya manusia di dunia ini, sebagaimana ditegaskan oleh Didin Hafihuddin, bahwa tujuan pendidikan Islam paling tidak mencakup tujuh aspek, yaitu: (1) untuk menyadarkan manusia sebagai hamba Allah (ta'abbud) secara totalitas, (2) sebagai khalifatullah (penguasa-penguasa di bumi), (3) sebagai mahluk yang sangat mulia dan sempurna dibandingkan mahluk-mahluk lain yang telah Allah Swt ciptakan, (4) supaya mampu melaksanakan amanah-amanah Allah Swt, (5) supaya mampu mengoptimalkan potensi yang dimilikinya sebagai bentuk syukur kepada Allah atas apa yang telah dianugerahkan kepadanya, (6) sebagai mahluk sosial agar manusia bertanggungjawab pada lingkungan (manusia dan alam semesta), dan(7) agar memiliki kemampuan beramal secara optimal dan ihsan dalam kehidupannya.[132]

2. Kurikulum Pendidikan

Menurut Abuddin Nata, sebagai seorang pemikir dan praktisi pendidikan Ki Hadjar dalam berbagai bukunya tidak terlibat dalam mengartikan kurikulum secara teknis. Namun secara substansial dapat dijumpai bahwa Ki Hadjar dengan caranya sendiri banyak membicarakan masalah kurikulum, yakni kurikulum dalam arti konvensional, yaitu nama-nama mata pelajaran yang perlu diajarkan kepada para siswa sesuai dengan tingkatannya.[133]

Tentang kurikulum pendidikan yang digagas oleh Ki Hadjar, menurut penulis, juga ada persamaan dan berbedaan dengan pendidikan Islam. Persamaannya adalah sama-sama menekankan budi pekerti dan menuntun anak didik agar menjadi manusia yang maju, cerdas dan berpengetahuan sosial kemasyarakatan yang akan memberi bekal pada anak untuk hidupnya kelak. Hal ini dibuktikan pada ungkapan Ki Hadjar, pelajaran yang dibolehkan kepada anak-anak boleh dibagi menjadi dua. Pertama, mata pelajaran yang selain memberi pengetahuan atau kepandaian juga berpengaruh kepada kemajuan batin, dalam arti memasakkan (mematangkan) pikiran, rasa dan kemauan. Sedangkan yang Kedua, adalah mata pelajaran yang akan memberi bekal pada anak-anak untuk hidupnya kelak dalam dunia pergaulan umum; yaitu mata pelajaran yang meliputi lapangan kultural dan kemasyarakatan.[134]

Juga ungkapannya, Bahwa pelajaran yang menajamkan pikiran dan berdasarkan kemasyarakatan itu umumnya menjadi pokoknya program pendidikan secara Barat, yang kita jumpai dalam sistem sekolah dengan ekorekornya: intelektualisme dan materialisme, yaitu mendewakan angan-angan dan keduniaan. Adapun pendidikan secara Timur yang sekarang juga mulai 
dimasukkan dalam cara pendidikan di Eropa, biasanya mengutamakan keluhuran budi pekerti.[135]

Melihat keterangan Ki Hadjar tentang kurikulum di atas, terlihat bahwa Ki Hadjar menginginkan agar bahan pelajaran yang diberikan kepada anak didik hendaknya mengarah pada pembentukan kepribadian dan budi pekerti untuk keluhuran hidup.

Tentunya jika dibaca dan dianalisa dalam perspektif pendidikan Islam, maka kurikulum Ki Hadjar ini juga terdapat ketidak sesuaian dengan kurikulum pendidikan Islam, karena kurikulum Ki Hadjar tidak mengaikatan dengan nilainilai agama (tauhid), melainkan kurikulum yang dimaksudkan untuk penajaman budi dan batin berdasarkan asas pancadharma. Sedangkan dalam pendidikan Islam, keterikatan antara kurikulum dan agama adalah sesuatu yang sangat urgen, vital, dan erat hubungannya dengan pembelajaran.

Muhaimin menegaskan, dalam penyusunan kurikulum pendidikan Islam diperlukan prinsip-prinsip umum sebagai landasan agar kurikulum yang dihasilkan sesuai dengan tujuan yang diharapkan baik oleh guru, siswa, orang tua maupun pemerintah. Prinsip-prinsip tersebut adalah pertautan yang sempurna dengan agama, yaitu setiap yang berkaitan dengan kurikulum, termasuk falsafah, tujuan, metode dan lainnya harus berdasar pada agama dan akhlak Islam.[136]

Abdurrahman al-Nahlawi juga menyatakan, bahwa kurikulum pendidikan Islam memiliki sistem pengajaran dan materi yang selaras dengan fitrah manusia agar dapat mewujudkan tujuan pendidikan Islam yang fundamental, bebas dari kontradiktif, efektif dan memberikan hasil pendidikan yang bersifat behavioristik.[137]

Ibnu Sina dalam bukunya al-Siyasah juga membentangkan pendapatpendapat berharga tentang kurikulum pendidikan anak-anak. Ia menasihatkan supaya pendidikan anak-anak dimulai dengan pelajaran al-Qur'an. Ibnu Tamam juga berkata, "Yang seharusnya dilakukan oleh bapak-bapak sesudah anakanaknya hafal al-Qur'an ialah mengajar mereka menulis, berhitung, dan berenang". Dengan demikian nyata bahwa menghafal al-Qur'an merupakan titik utama dalam pelajaran anak-anak di pondok pesantren.[138]

Akhirnya, menurut penulis dengan memperhatikan uraian di atas, dapat dipahami bahwa agama Islam sebagai sumber ilham kurikulum dalam menciptakan falsafah dan tujuannya menekankan kepentingan duniawi dan ukhrawi dengan memperhatikan perkembangan psikologis anak dan lingkungan sosial yang tetap menggunakan timbangan al-Qur'an sebagai kurikulum inti dalam pelaksanaan kependidikan Islam, hal ini ada perbedaan yang nampak jelas dengan kurikulum yang digagas Ki Hadjar yang berdasarkan Pancadharma.

3. Metode Pendidikan

Tentang metode, dalam bab II disebutkan bahwa metode-metode pendidikan Islam adalah: tamsil, ceramah, keteladanan, latihan pengalaman, diskusi, tanya jawab, demonstrasi, pemberian motivasi dan peringatan. Sedangkan pada bab IV dijelaskan, metode pengajaran Ki Hadjar ada lima macam yaitu: metode memberi contoh, metode pembiasaan, metode pengajaran, metode perintah-paksaan-hukuman (meskipun Ki Hadjar sendiri tidak sependapat dengan metode ini, karena dianggapnya bertentangan dengan asas kemerdekaan), metode laku, metode pengalaman lahir dan batin (ngerti, ngrasa dan nglakoni). 
Memperhatikan kelima metode pengajaran yang ada pada pemikiran Ki Hadjar secara global ada sedikit kemiripannya, di samping ada hal yang tidak sesuai. kemiripannya diantaranya pada metode memberi contoh (uswah hasanah), metode pembiasaan, metode pengajaran, metode laku, metode pengalaman lahir dan batih (ngerti, ngrasa, nglakoni). Sedangkan perbedaannya terletak pada sisi pengistilahan, dimana metode pendidikan yang digunakan Ki Hadjar banyak banyak menggunakan istilah Jawa.

Namun, meskipun sederhana dan tidak banyak seperti metode pengajaran Islam, kelima metode yang digagas Ki Hadjar mencakup tiga aspek domain yaitu kognitif, afektif, dan psikomotorik. Misalnya, dengan metode pengajaran secara tidak langsung terjadi proses intelektualisasi sehingga tingkat penguasaan ilmu seseorang semakin meningkat. Dengan laku pada proses selanjutnya, murid akan melakukan dan mengkontekstualisasikan pelajaran yang didapatnya.

Ketidak sesuaian metode pendidikan Ki Hadjar dengan Islam adalah terletak dari tujuan akhir dari metode itu; dimana metode Ki Hadjar adalah cara (metode) mendidik guru agar anak bisa berkembang secara maksimal sesuai kodrat alamnya untuk meraih cita-cita luhur yang diinginkan. Sementara dalam metode pendidikan Islam adalah cara mendidik guru agar anak bisa berkembang secara maksimal dan berlaku baik agar kelak menjadi manusia yang bisa masuk surga.

Abdul Madjid mengungkapkan, bahwa proses belajar-mengajar merupakan interaksi yang dilakukan antara guru dan siswa, oleh karena itu metode pengajaran yang dipergunakan dalam pendidikan agama Islam harus dilaksanakan secara sistemis, sebagaimana metode pengajaran yang terjadi pada Nabi Muhammad, Seperti apa yang disabdakannya:

"Bagi segala sesuatu itu ada metodenya, dan metode masuk surga adalah ilmu" (HR. Dailami).[139]

4. Guru

Tentang Guru, dalam bab II Poerwadarminta menjelaskan, bahwa yang dimaksud pendidik secara bahasa adalah orang yang mendidik. sedangkan Abdullah Aly mendeskripsikan peran guru agama Islam adalah sebagai berikut: (1) sebagai murabbi, guru harus mengembangkan, mengatur, dan memelihara potensi, minat, bakat, dan kemampuan siswa secara bertahap ke arah akulturasi diri, (2) sebagai muallim, guru harus melakukan transfer ilmu dan nilai kepada siswa, (3) sebagai mursyid, guru harus melakukan transinternalisasi kepribadian dan akhlak siswa, (4) sebagai muaddib, guru harus membangun peradaban masa depan yang berkualitas melalui pendidikan, (5) sebagai mudarris, guru harus mencerdaskan siswa baik secara intelektual, emosional, maupun spiritual.[140]

Sedangkan Ki Hadjar menggunakan istilah guru adalah seorang pamong yang harus "digugu" dan "ditiru". Untuk itu, guru atau si pengajar harus seorang yang berpengetahuan dan berpengalaman, paling sedikit harus yang suci hidupnya, lahir dan batin.[141] Guru, masih menurut Ki Hadjar Dewantara tidak hanya memberi pengetahuan yang perlu dan baik saja, akan tetapi harus juga mendidik si murid agar dapat mencari sendiri pengetahuan itu dan memakainya guna amal keperluan umum. Pengetahuan yang baik dan perlu yaitu yang manfaat untuk keperluan lahir dan batin dalam hidup bersama.[142]

Memperhatikan uraian di atas dapat disimpulkan bahwa konsep guru menurut pemikiran pendidikan Ki Hadjar terdapat kemiripan dari segi menuntun atau membimbing murid; akan tetapi terdapat ketidak sesuaian dengan pendidikan Islam, yang mana dalam pendidikan Islam konsep guru (mu'allim) 
harus bisa mengarahkan anak didik menjadi manusia yang berakhlak Islami, melaksanakan amar ma'ruf dan nahi munkar sebagi aplikasi ajaran Islam agar menjadi manusia yang bertakwa kepada Allah Swt.

Sedangkan konsep guru dalam pendidikan Ki Hadjar sebagai sarana menuntun di dalam hidup tumbuhnya anak-anak dengan segala kekuatan kodrat yang ada pada anak-anak itu agar mereka sebagai manusia dan sebagai anggota masyarakat dapat mencapai keselamatan dan kebahagiaan yang setingi-tinginya.

Hal inilah yang membuat konsep guru Ki Hadjar Dewantara tidak sesuai dengan konsep guru dalam pendidikan Islam.

5. Murid

Tentang konsep murid dalam pendidikan Ki Hadjar perespektif pendidikan Islam, ditemukan beberapa kemiripan dengan konsep guru sebagaimana pembahasan di atas. Ki Hadjar mendudukkan anak didik sesuai dengan posisinya. Ia sadar bahwa sebagai manusia, anak didik itu adalah manusia yang belum dewasa yang masih tergantung kepada pamongnya, anak didik itu memiliki kekurangankekurangan tertentu, anak didik masih sangat terbatas dibandingkan dengan kemampuan pamongnya. kekurangan ini akhirnya membawa anak didik tersebut mengadakan interaksi dengan pamongnya dalam situasi pendidikan.

Secara universal, Ki Hadjar mempunyai konsep yang bagus tentang murid pada pendidikan di sekolah rendah. Menurutnya, sebaiknya murid laki-laki itu dicampur dengan murid perempuan, hal ini diperuntukkan supaya murid-murid laki-laki takut bersifat kasar dan berhati-hati dalam berkata-kata serta untuk menghaluskan dan mensucikan suasana di dalam kelas. Sedangkan pada muridmurid di sekolah menengah menurutnya, sebaiknya di pisahkan antara murid laki-laki dengan murid-murid perempuan, karena menurutnya masa itu adalah masa menjelang mulainya birahi, sehingga sukar sekali pada anak untuk belajar, juga tujuan dipisahkannya murid laki-laki dan perempuan adalah agar para murid mudah memusatkan fikirannya untuk belajar.

Akan tetapi konsep murid ini, tidak disertai dengan proses bagaimana murid itu benar-benar menjadi murid yang beriman dan bertakwa kepada Allah yang bisa mengamalkan konsep amar ma'ruf dan nahi munkar sebagi aplikasi ajaran Islam agar menjadi manusia yang bahagia setinggi-tingginya baik di dunia dan akherat kelak. inilah yang membuat konsep murid Ki Hadjar Dewantara tidak sesuai dengan konsep murid dalam pendidikan Islam.

6. Evaluasi

Sebagaimana diuraikan dalam bab IV bahwa Ki Hadjar tidak mengemukakan evaluasi pendidikan secara eksplisit. Namun dari berbagai pernyataannya dapat dilihat dan dijumpai bahwa ia memiliki sistem evaluasi pendidikan tersebut. Misalnya Ki Hadjar mengatakan, merdeka baik secara fisik, mental dan kerohanian, namun kemerdekaan pribadi ini dibatasi oleh tertib damainya kehidupan bersama dan ini mendukung sikap-sikap seperti keselarasan, kekeluargaan, musyawarah, toleransi, kebersamaan, demokrasi, tanggungjawab dan disiplin.[143]

Serta pernyataanya, berilah Kemerdekaan dan kebebasan kepada anakanak kita; bukan kemerdekaan yang leluasa, namun yang terbatas oleh tuntutantuntutan (Kodrat alam) yang hak atau nyata, dan menuju ke arah (Kebudayaan), yakni keluhuran dan kehalusan hidup manusia. Agar kebudayaan tadi dapat menyelamatkan dan membahagiakan hidup dan penghidupan diri dan masyarakat, maka perlulah dipakainya dasar (Kebangsaan), akan tetapi jangan 
sekali-kali dasar ini melanggar atau bertentangan dengan dasar yang lebih luas, yaitu dasar (Kemanusiaan).[144]

Dengan memperhatikan pertanyaan tersebut di atas, tampak sekali bahwa evaluasi dalam pendidikan Ki Hadjar Dewantara adalah tidak serta merta anak didik diberi kebebasan serta dibiarkan melakukan sesuai dengan kehendaknya dan tanpa kontrol. Evaluasi disini sangat dibutuhkan agar anak bisa menuju kearah yang diharapkan oleh pamong dengan arahan dan tuntunan yang benar, serta tidak menyimpang dari kodrat alam. Peran evaluasi pendidikan dibutuhkan, agar anak didik tetap berjalan sesuai dengan tujuan pendidikan yaitu memanusiakan manusia dan memberi kebebasan untuk mengangkat harkat, martabat dan kemajuan umat manusia secara universal.

Sedangkan evaluasi dalam pendidikan Islam merupakan cara atau teknik penilaian terhadap tingkah laku manusia-didik secara komprehensif dari seluruh aspek mental-psikologis dan spiritual-religius.[145]

Kedudukan dan fungsi evaluasi dalam pendidikan Islam adalah sebagai input untuk melakukan perbaikan kegiatan pendidikan. Selain itu evaluasi berfungsi sebagai selektif, diagnotik, penempatan dan sebagai pengukur keberhasilan.[146]

Meskipun sebagian pakar beranggapan bahwa istilah evaluasi belum dijumpai pada abad klasik dan tengah. Tetapi dari segi fenomenanya prinsip dan praktik evaluasi dapat ditemukan pada abad klasik dan tengah. Misalnya, Nabi Muhammad Saw melakukan evaluasi untuk memilih seorang hakim dan pemimpin perang, juga dapat ditemukan dalam pernyataan khalifah Umar bin Khattab:

Hisab atau evaluasilah diri kalian sebelum kalian dievaluasi.[147]

Agus Handoko menyatakan, sebaiknya seorang Muslim mengevaluasi diri terhadap apa yang telah dilakukan dan bersiap untuk menggapai masa depan yang lebih baik. Hal ini sesuai dengan firman Allah Swt dalam Surat al-Hasyr, ayat 18:

Hai orang-orang yang beriman bertakwalah kamu sekalian kepada

Allah, dan hendaklah setiap diri, mengevaluasi kembali apa yang

telah dilakukan untuk menata hari esok. Dan bertakwalah kamu

sekalian kepada Allah, sesungguhnya Allah Maha mengetahui apa

yang kalian kerjakan.[148]

Melihat uraian di atas tampak sekali ada hal yang tidak sesuai antara konsep evaluasi Ki Hadjar dengan konsep evaluasi Islam. Dalam Islam konsep evaluasi dijalankan atas dasar intropeksi diri atas perbuatannya yang telah dilakukan agar tidak mengulangi lagi pada hal-hal yang dilarang sebagai wasilah menuju ketakwaan kepada Allah Swt sebagaimana ayat tersebut di atas. Sedangkan evaluasi Ki Hadjar secara normatif mengajarkan agar seseorang bisa berfikir dan intropeksi atas usahanya sebagai wasilah menjadi manusia yang baik dan berbudi luhur serta selaras dengan kodrat alam.

Dengan demikian, terlihat jelas bahwa sistem pendidikan Ki Hadjar Dewantara tidak sesuai dengan sistem pendidikan dalam Islam. Berikut gambaran singkat jika kedua sistem pendidikan itu digabungkan dalam sebuah tabel.

F.Analis Corak Pemikiran Ki Hadjar dan Pemikirannya dijadikan Dasar Pendidikan Nasional.

1. Corak Pemikiran Pendidikan Ki Hadjar

Bambang Sukowati Dewantara, putra dari Ki Hadjar Dewantara dalam bukunya berjudul Ki Hadjar Dewantara Ayahku, menyatakan "bahwa corak pendidikan yang digagas Ki Hadjar adalah suatu dasar pendidikan yang berbentuk 
nasionalistik dan universal". Lebih lanjut Bambang menyatakan, landasan filosofisnya nasionalistik dan universalistik. Nasionalistik maksudnya adalah budaya nasional, bangsa yang merdeka dan independen baik secara politis, ekonomis, maupun spiritual. Universal artinya berdasarkan pada hukum alam (natural law).[149]

Corak pemikiran Ki Hadjar yang nasionalisti ini juga dipertegas Moch. Tauchid yang menyatakan bahwa yang diwarisi jasa-jasa dari jiwa pendidik Ki Hadjar adalah pendidikan yang tidak memihak golongan, akan tetapi pendidikan bersifat nasional.[150]

Sedangkan menurut analisi penulis, pandangan Ki Hadjar tentang konsepsi pendidikanya ini bercorakkan nasionalistik-sekular. Nasionalistik karena konsep pendidikannya berdasar dan bersumberkan pada prinsip budaya bangsa sendiri yaitu bangsa Indonesia, sebagaimana dalam asas Pancadharmanya yang berisikan kebangsaan dan kebudayaan, yaitu pendidikan yang selaras dengan produk budaya bangsa dan tidak meniru budaya barat. Sekular, karena Ki Hadjar memisahkan konsep pendidikannya dengan nilai-nilai keagamaan yang inti ajarannya adalah tauhid dan keimanan.

Tauhid dan keimanan tidak nampak dalam dasar pendidikan Ki Hadjar, padahal tauhid dalam pandangan pendidikan Islam adalah essensi dari pendidikan itu sendiri, yaitu sebagai bentuk dan wujud nyata pengakuan hamba kepada Tuhannya. Pengakuan "iman" dengan meyakini bahwa inti dan tujuan dari diciptakannya manusia di bumi tidak lain untuk beribadah kepada Tuhannya. Hal ini juga selaras dengan pengamalan pancasila sila kesatu yang berbunyi, "Ketuhanan Yang Maha Esa".

Sekularisasi pendidikan yang dilakukan Ki Hadjar ini sangat mendasar dan tidak tanpa alasan, mengingat ia menghendaki suatu pendidikan yang tidak memihak golongan, pendidikan yang tidak bersumber dari satu agama tertentu, tetapi pendidikan yang universal yang bisa merangkul semua unsur agama, golongan dan ras, terlebih Indonesia adalah negara dengan masyarakatnya yang plural terdiri dari beraneka ragam suku, ras, agama dan kepercayaan.

Sekularisasi pendidikan ini juga berangkat dari perjalanan sejarah Indonesia, yaitu konflik Islam-Kristen tentang masalah Piagam Jakarta. Hal ini sangat berkaitan dan berimbas besar pada semua aspek pemikiran dan kebijakan di Indonesia. Kelompok nasionalis-sekular dengan tegas menolak klausal dimasukkannya "kewajiban melaksanakan syariat Islam bagi kaum Muslim Indonesia" dalam konstitusi. Sementara ketua BPUPKI yang merupakan aktifis Gerakan Teosofi, yaitu Radjiman Widijodiningrat menyimpulkan: "Jadi, rancangan ini sudah diterima semuanya... dengan suara bulat diterima Undang-undang Dasar ini.".[151]

Kelompok Kristen juga dengan tegas menolaknya, penolakan terhadap Piagam Jakarta oleh pihak Kristen dapat ditelusuri pada sikap Latuharhary di BPUPKI. Seperti diketahui, pada tanggal 18 Agustus 1945, Piagam Jakarta yang sudah disepakati di BPUPKI di hapus, dengan alasan ada keberatan dari pihak Kristen Indonesia Bagian Timur. Konon, datanglah seorang utusan dari Indonesia Bagian Timur, melalui opsir Tentara Jepang yang waktu itu masih berwenang di Jakarta. Utusan tersebut menyampaiakan pesan kepada Bung Karno dan Bung Hatta. Opsir Jepang itu mengaku, membawa pesan dari umat Kristen di Indonesia bagian Timur. Berisikan pesan, "ada tujuh kata yang tercantum dalam Mukaddimah UUD 1945 yang harus dicabut. Kalau tidak, umat Kristen di Indonesia sebe- 
lah Timur tidak akan turut serta dalam negara Republik Indonesia yang baru saja diploklamirkan. Tujuh kata yang harus dicoret itu berbunyi, "dengan kewajiban menjalankan syariat Islam bagi pemeluk-pemeluknya”.[152]

Mohammad Natsir menyebut peristiwa itu (18 Agustus 1945) sebagai "peristiwa ultimatum terhadap Republik Indonesia yang baru saja diploklamirkan".[153]

Tokoh-tokoh Kristen selalu menolak menolak usaha untuk mengembalikan Piagam Jakarta dalam Konstitusi Indonesia. Pemuatan "tujuh kata" dalam Mukaddimah UUD 1945, dikatan oleh Pendeta Oktavianus sebagai "ide akan membentuk Indonesia menjadi negara agama", sehingga "Indonesia bagian Timur dengan tegas menolak dan hanya mau bergabung dengan Republik jika Indonesia menjadi negara kesatuan".

Mengomentari ultimatum pihak Kristen pada tahun 1945 itu, Mohammad Natsir menulis:

Utusan tersebut tidak untuk mengadakan diskusi tentang persoalannya. Hanya menyampaikan satu peringatan. Titik! Tak perlu bicara lagi. Terserah apakah pesan itu diterima atau tidak. Asal tau apa konsekuensinya. Itu berupa ultimatum. Ultimatum bukan saja terhadap warga negara yang beragama Islam di Indonesia. Tetapi pada hakekatnya terhadap Republik Indonesia sendiri yang baru berumur 24 jam itu. Hari 17 Agustus adalah hari proklamasi, hari raya kita. Hari raya 18 Agustus adalah hari ultimatum dari umat Kristen Indonesia bagian Timur. Kedua-duanya peristiwa itu adalah peristiwa sejarah. Kalau yang pertama kita rayakan, yang kedua sekurang-kurannya jangan dilupakan. Menyambut hari Proklamasi 17 Agustus kita bertahmied, menyambut hari besoknya 18 Agustus kita beristighfar. Insya'allah umat Islam tidak akan lupa.[154]

Muhammad Natsir menyatakan, "kaum Kristen sangat konsisten dalam menjalankan ultimatum 18 Agustus 1945. Sungguhpun tujuh kata itu sudah digugurkan. Tetapi mereka tidak puas begitu saja." Natsir menambahi, di bidang legislatif, kaum Kristen berusaha keras menggagalkan setiap usaha pengesahan Undang-undang yang diinginkan kaum Muslim untuk dapat lebih mentaati ajaranjaran agama mereka.

Menurut Adian Husaini, usaha kaum Muslim selalu gagal dalam mengembalikan Piagam Jakarta. Bahkan setelah reformasi tahun 1998 terjadi perubahan besar dalam sikap tokoh-tokoh Islam Indonesia tentang Piagam Jakarta.[155] Berbeda dengan sikap tokoh-tokoh Islam, sikap pihak Kristen tidak pernah berubah sejak 1945, yakni menolak keras dikembalikannya Piagam Jakarta ke dalam konstitusi Indonesia (UUD 1945).

Bahkan ada yang berpendapat, pemikiran pendidikan Ki Hadjar Dewantara bercorakkan Nasionalistik-Kebatinan. Hal ini sebagaimana diungkapkan Hamka dalam bukunya berjudul: Perkembangan Kebatinan di Indonesia, yang dikutip Artawijaya, bahwa Tamansiswa adalah gerakan abangan, klenik, dan primbon Jawa, yang menjalankan ritual shalat daim. Dalam kepercayaan kebatinan, shalat di sini bukan bermakna ritual seperti yang dijalankan umat Islam, tetapi shalat dalam pengertian kebatinan, yaitu menjalankan kebaikan terus menerus. Inilah yang dimaksud dengan shalat daim.[156]

Menurut penulis, istilah shalat daim yang dilakukan Ki Hadjar ini sangat bertentangan dengan konsep shalat dalam agama Islam, karena dalam Islam su- 
dah dijelaskan proses, cara, syarat dan rukunnya yang harus dipenuhi seseorang yang hendak shalat. Shalat dalam Islam bukan sekedar melakukan kebaikan terus menerus, tapi shalat dalam Islam adalah kontak hubungan antara hamba dengan Tuhannya sebagai bentuk ritual yang bernilai ibadah dan keimanan. Sementara konsep shalat daim yang anut Ki Hadjar sepi dari nilai keimanan dan tauhid.

Bung Karno menegaskan, bahwa apa yang dilakukan oleh Ki Hadjar adalah berangkat dari panggilan mistik. Lebih lanjut Bung karno, seperti dikutip Artawijaya menyimpulkan, bahwa apa yang dilakukan oleh Ki Hadjar Dewantara adalah berangkat dari panggilan mistik. Sebuah small group discussion yang membicarakan tentang kebatinan, yang diselenggarakan setiap Selasa Kliwon dan dipimpin oleh Pangeran Soeryamataram adalah cikal bakal berdirinya Tamansiswa.

Peserta diskusi kebatinan ini mendapat sebutan ketika itu dengan "Gerombolan Seloso Kliwon". Mereka adalah, Ki Hadjar Dewantara, R.M Soetatmo Soerjokoesoemo, R.M.H Soerjo Poetro, Ki Pronowidigdo, Ki Sutopo Wonoboyo, Ki Surjodirjo, BRM Subono, dan Pangeran Soeryamataram. Setiap pertemuan, mereka mendiskusikan hal-hal yang berkaitan dengan kebatinan, yaitu usaha untuk "membahagiakan diri, membahagiakan bangsa, dan umat manusia." Inilah yang menjadi asas Tamansiswa yaitu perpaduan antara pendidikan Barat dan kebatinan dalam mewujudkan suatu kemerdekaan batin, kemerdekaan pikiran dan kemerdekaan tenaga.[157]

Sementara menurut analisis Artawijaya, bahwa corak kebatinan ini terlihat jelas dengan asas dan keyakinan Tamansiswa yang dianggap jauh dari nilai Ketuhanan dan lebih mementingkan kebatinan dan kemanusiaan. Menurut Aratawijaya, hal itu tak berlebihan, karena dalam beberapa pidato para petinggi Tamansiswa, termasuk pemikiran pendirinya Ki Hadjar Dewantara, corak kebatinan dan Teosofi begitu kental terasa. Hal ini diperkuat lagi, ketika Tamansiswa menyatakan bahwa dalam menjalankan roda pendidikannya, mereka menggunakan "Tiga Sistem Among", yaitu: Mengabdi kepada prikemanusiaan, membangun kepribadian sesuai kodrat alam, dan membangun kemerdekaan. Sekali lagi, tidak disebut sedikitpun tentang Ketuhanan.[158]

Salah satu media massa yang dikelola oleh para aktivis Masyumi "Mingguan Abadi" juga mengkritik pemikiran Ki Hadjar dengan Tamansiswanya, dalam artikelnya, Abadi menilai tidak dicantumkannya soal ketuhanan mencerminkan bahwa Tamansiswa jauh dari kepercayaan terhadap ketuhanan dan lebih mementingkan kemanusiaan. Tamansiswa juga dinilai mengabaikan sila Ketuhanan yang tercermin dalam ideologi negara, Pancasila.[159]

Janquire, seorang residen Belanda juga dengan tegas menyatakan bahwa cita-cita Tamansiswa adalah "anti-Tuhan" dan "anti-agama". Tudingan Janquire ini dianggap oleh aktifis Tamansiswa sebagai propaganda dan adu domba yang bertujuan memojokkan Tamansiswa. Oleh karena itu, untuk membantah tudingan mingguan Abadi dan Janquire, Tamansiswa melalui seorang aktifisnya bernama Muhammad Tauchid kemudian membuat bantahan dan klarifikasi dalam sebuah pidato yang cukup memukau para anggotanya. Tauchid menepis segala tudingan miring terhadap Tamansiswa dan meyakinkan masyarakat bahwa organisasi mereka tidak akan mengabaikan nilai-nilai ketuhanan.[160]

Corak Nasionalis-Kebatinan juga terlihat pada konsep pendidikan Ki Hadjar, sebagaimana yang tercantum dalam bukunya berjudul Asas-asas dan Dasar-dasar 
Tamansiswa, Ki Hadjar menegaskan, "bahwa tiap-tiap pendidikan berkewajiban memelihara dan meneruskan dasar-dasar dan garis-garis hidup yang terdapat dalam tiap-tiap aliran kebatinan dan kemasyarakatan, untuk mencapai keluhuran dan kehalusan hidup dan kehidupan menurut masing-masing aliran yang menuju ke arah adab kemanusiaan.".[161]

Pernyataan Ki Hadjar ini menegaskan bahwa ia menghendaki pendidikan dan pengajaran kepada rakyat untuk mempertinggi dan menyempurnakan hidup dan penghidupan rakyat yang harus dilakukan sebaik-baiknya dengan mengingati atau memperhatikan segala kekhususan dan keistimewaan yang bertali dengan hidup kebatinan dan kemasyarakatan yang sehat dan kuat, serta memberi kesempatan pada tiap-tiap warga negara untuk menuntut kecerdasan budi, pengetahuan dan kepandaian yang setinggi-tingginya menurut kesanggupannya masing-masing.[162]

Dengan demikian, melihat uraian di atas, menurut analisis penulis bahwa pemikiran pendidikan Ki Hadjar bercorakkan Nasionalis-Sekular. Nasionalis, karena berdasarkan kebudayaan bangsa, yaitu pendidikan yang bisa membawa semua anggota masyarakat dari berbagai lapisan dan keyakinan untuk bisa meraih kebebasan, kemanusiaan dan kebahagiaan yang setinggi-tingginya. sekular karena konsepsinya terpisahkan dengan nilai-nilai ketauhidan. Sementara corak pendidika Islam adalah konsep yang intregatif (gabungan nilai-nilai dunia dan akhirat), komprehensif, ta'abbudi (bernilai ibadah kepada Allah Swt) serta bersendikan tauhid.

2. Sebagai Dasar Pendidikan Nasional

Konsepsi pendidikan nasional yang diciptakan Ki Hadjar, pada zaman penjajahan dilaksanakan dengan menanamkan jiwa merdeka dan jiwa nasional guna melawan penjajahan; selanjutnya untuk mengisi kemerdekaan dan menuju masyarakat yang adil dan makmur, Tamansiswa merumuskan suatu gagasan, yaitu untuk mewujudkan manusia merdeka lahir batin, salam dan bahagia, menuju masyarakat tertib dan damai. Konsepsi (prasaran) Ki Hadjar mengenai pendidikan nasional ini, diterima oleh konggres Perkumpulan Partai-partai Politik Kebangsaan Indonesia (PPPKI) di Surabaya tepatnya pada tanggal 31 Agustus 1928.

Begitu juga pada era Indonesia memproklamasikan kemerdekaannya pada tanggal 17 Agustus 1945, pada kabinet pertama, Ki Hadjar duduk sebagai Menteri Pendidikan Pengajaran dan Kebudayaan (PPK). Pada era itu, nama Ki Hadjar bukan saja diabadikan sebagai seorang tokoh pendidikan nasional; bahkan tanggal lahirnya pun (2 Mei) dijadikan sebagai hari Pendidikan Nasional. Sebagaimana dalam Keputusan Presiden No. 316 tahun 1959. Juga melalui surat Keputusan Presiden RI No.305 Tahun 1959, tanggal 28 November 1959 Ki Hadjar ditetapkan sebagai Pahlawan Pergerakan Nasional.

Meskipun banyak pro dan kontra tanggal lahirnya Ki Hadjar dijadikan hari pendidikan nasional, tapi menurut Muchammad Tauchid, seorang aktifis Tamansiswa, sesungguhnya ketetapan tersebut sudah tepat. Karena berkat konsepsinya dibidang pendidikan, antara lain: teori tripusat, sistem among, tut wuri handayani, panca dharma, dan lain-lainnya serta tex books ilmu pendidikan telah mensejajarkan Ki Hadjar dengan tokoh-tokoh pendidikan dunia, seperti Frobel, Montessorie, Peztalozzi, John Dewey, Rabindranat Tagore, dan lain-lain. Yang kita warisi jasa-jasa dan jiwa pendidik Ki Hadjar yang tidak memihak golongan, tetapi bersifat nasional bukan Tamansiswanya.[163] 
Sementara kelompok yang menolak 2 Mei dijadikan sebagai hari pendidikan nasional. karena menurut pendapat PGRI, pada 2 Mei itu adalah hari lahir Ki Hadjar. Hal ini dihawatirkan akan berbau kultus individu, dan ini bertentangan dengan semangat dan jiwa Orde Baru serta kemurnian Pancasila dan UUD 1945. Juga karena Ki Hadjar dan Tamansiswanya dengan dasar "Tri-Darmanya" ternyata dijadikan alat ampuh oleh PKI dan simpatisannya untuk menghilangkan sila Ketuhanan Yang Maha Esa, sebagai sila pertama dan utama dalam Pancasila. Menurut pendapat PGRI adalah lebih tepat bila tanggal 25 Nopember dijadikan sebagai hari pendidikan nasional karena justru hari tersebut merupakan momentum yang sangat penting bagi dunia pendidikan/keguruan. Pada hari itu terjadi suatu perubahan sikap /mental kaum pendidik dari seluruh pelosok tanah air yang penuh heroisme untuk mengikis habis pengaruh kolonialisme /imperialisme, feodalisme, dan sukuisme seperti tercantum dalam Mukaddimah AD/ART-nya.

Lebih lanjut Moch. Tauchid menyatakan:

... Cita-cita Ki Hadjar telah berhasil turut menjiwai sistem pendidikan nasional kita pada khususnya dan perjuangan bangsa Indonesia pada umumnya. Hal ini, sama sekali tidak berarti bahwa kita mengurangi arti ataupun mengecilkan sumbangan dan peranan perjuangan tokoh-tokoh pendidikan nasional yang lain, yang juga telah merintis jalan ke arah terwujudnya pendidikan nasional berdasarkan Pancasila.[164]

Sedangkan Abuddin Nata berkesimpulan, bahwa berbagai konsep strategis tentang pendidikan di Indonesia, hampir seluruh aspeknya merujuk pada pemikirannya. Lebih lanjut ia menyatakan:

Ki Hadjar Dewantara adalah seorang pakar yang berkecimpung atau mengonsentrasikan keahliannya dalam bidang pendidikan. Amatlah naif apabila tidak mengetahui dan memahami pemikiran pendidikan Ki Hadjar Dewantara. Hal yang demikian itu terjadi antara lain disebabkan karena berbagai konsep strategis tentang pendidikan di Indonesia dalam hampir seluruh aspeknya senantiasa merujuk pada pemikiran Ki Hadjar Dewantara.

Selain konsep strategis tentang pendidikan di Indonesia, ternyata gagasan dan pemikiran Ki Hadjar juga dijadikan sebagai acuan penyelenggaraan pendidikan nasional hingga sekarang. Hal ini sebagaimana diungkapkan Abuddin:

Berbagai aspek yang terkait dengan pendidikan seperti visi, misi, tujuan, kurikulum, dan tahapan pendidikan harus dirumuskan berdasarkan kemauan bangsa Indonesia sendiri. Gagasan dan pemikiran Ki Hadjar Dewantara inilah yang kemudian menjadi acuan penyelenggaraan pendidikan nasional hingga sekarang.

Bahkan prinsip pendidikan yang berbunyi ing ngarso sung tulodo, ing madya mbangun karso, dan tut wuri andayani juga berasal dari buah pemikirannya. Sedangkan menurut Abdurrahman Suryomiharjo, usaha Ki Hadjar untuk menyelenggarakan pendidikan nasional dimulai pada 03 Juli 1922 dengan mendirikan Perguruan Kebangsaan Tamansiswa yang pertama di Yogyakarta. Sejak saat didirikan perguruan tersebut, nama Ki Hadjar tidak dipisahkan lagi dari Tamansiswa; sehingga Ki Hadjar dapat predikat sebagai bapak Tamansiswa sekaligus bapak pendidikan nasional.

3. Pendidikan Tamansiswa dan Pendidikan Islam Masa Kini 
Sebagaimana diungkapkan Wuryadi, ketua Majelis Luhur III Bidang Pendidikan dan Kebudayaan Persatuan Tamansiswa Yogyakarta, "Ki Hadjar yang tanggal lahirnya diperingati sebagai Hari Pendidikan Nasional, akhir-akhir ini ajarannya mulai banyak ditinggalkan." Lebih lanjut Wuryadi menegaskan, bahwa konsep pendidikan yang dikembangkannya di Tamansiswa kini terpinggirkan dan mulai banyak ditinggalkan, pendidikan ajaran Ki Hadjar Dewantara ternyata tidak berorientasi pada kepentingan global, pendidikan yang dikembangkan sekarang ini berbeda orientasinya, dalam sejumlah hal, kebijakan nasional dalam hal pendidikan sangat berbeda dengan konsep pendidikan yang dikembangkan Ki Hajar Dewantara.[165]

Melihat uraian Wuryadi di atas, terlihat jelas bahwa konsep pendidikan Ki Hadjar Dewantara sudah berubah, terpinggirkan, mulai banyak ditinggalkan, dan sangat berbeda dengan kebijakan nasional tentang pendidikan. Apalagi dalam situasi reformasi sekarang ini, dimana konsep pendidikan di Indonesia yang tengah ditinjau ulang, untuk kemudian dihasilkan suatu rumusan konsep pendidikan yang sesuai dengan tuntutan zaman".[166]

Sedangkan menurut analisis Artawijaya, dibanding Ki Hadjar Dewantara dengan Tamansiswanya, KH. Achmad Dahlan dengan Persyarikatan Muhammadiyah dinilainya lebih memiliki peran besar dalam pendidikan nasional. Ki Hadjar bercorakan kebatinan dan barat, karena menurutnya Ki Hadjar banyak terpengaruh oleh pemikiran barat seperti Maria Montessori, Robindranath Tagore dan Rudolf Steiner, sedangkan Kiai Dahlan bercorakkan Islam dan nasional, hal demikian dikarenakan kiprah KH. Achmad Dahlan dan Muhammadiyah lebih berperan dalam memajukan pendidikan nasional, Achmad Dahlan dinilainya kental dengan corak pemikiran Islam dan nasionalis, anti kolonialisme, tidak terpengaruh paham barat, dan mengembangkan lembaga pendidikan untuk mengantisipasi besarnya arus Kristenisasi pada masa itu yang dibawa oleh lembaga-lembaga pendidikan yang didirikan oleh pemerintah kolonial.[167]

Sedangkan mengenai perguruan dan lembaga pendidikan pada masa Orde Baru dan era reformasi sekarang ini, terlihat jelas bahwa Perguruan Tamansiswa mengalami kemunduran dan semakin terpinggirkan, hal yang demikian sebagaimana diungkapkan Wuryadi di atas, sedangkan perguruan Islam, seperti Muhammadiyah, kini mengalami kemajuan signifikan dan progresifitas. Hal ini bisa dilihat perguruan yang berlandaskan nilai-nilai ke-Islam-an seperti $\mathrm{Mu}$ hammadiyah: Universitas Muhammadiyah Malang (UMM) yang berperingkat 18 perguruan tinggi di Indonesia, Universitas Muhammadiyah Yogyakarta (UMY) berperingkat 19, dan Universitas Muhammadiyah Surakarta (UMS) berperingkat 25 perguruan tinggi di Indonesia, versi Webmetrics Juli 2012.[168]

Ketiga perguruan Muhammadiyah itu adalah salah satu contoh perguruan yang berasaskan Islam dan bersumberkan wahyu Ilahiyah (al-Qur'an dan alHadits), yang mampu bertahan dan tetap kokoh dengan jati dirinya, bahkan mengalami peningkatan kualitas dan kuantitasnya.

Universitas Muhammadiyah Malang misalnya, perguruan yang terkenal dengan "The White Campus" ini mempunyai misi: "Menjadikan universitas terkemuka dalam pengembangan ilmu pengetahuan, teknologi, dan seni (IPTEKS) berdasarkan nilai-nilai Islam." Misi-nya: 1) Menyelenggarakan pendidikan yang bermutu, 2) Menyelenggarakan penelitian dan pengabdian kepada masyarakat yang dapat meningkatkan kesejahteraan manusia, 3) Menyelenggarakan pengelolaan universitas yang amanah, 4) Menyelenggarakan civitas akademika 
dalam kehidupan yang Islami sehingga mampu beruswah khasanah, dan 5) Menyelenggarakan kerjasama dengan pihak lain yang saling menguntungkan dalam pengembangan IPTEKS.[169]

Konsep pendidikan Islam pada UMM juga terlihat pada lambang dan simbolnya yang penuh dengan nilai-nilai filosofis ke-Islam-an, seperti UMM berlambangkan "Matahari Bersinar 12" dengan "Dua Kalimat Syahadat" bermaksud sebagai ikrar dalam ajaran Islam, yaitu kesaksian bahwa tidak ada Tuhan selain Allah dan Pengakuan Muhammad sebagai utusan Allah. Gambar "Padi dan Kapas" bermaksud memperjuangkan adil dan makmur berupa sandang dan pangan serta tabiat seperti padi "semakin berisi semakin merunduk", dan tulisam arab "Muhammadiyah" yang bermakna, sebagai pengikut ajaran Nabi $\mathrm{Mu}$ hammad Saw.[170]

Dengan demian terlihat jelas bahwa konsep pendidikan yang berdasarkan nilai-nilai ke-Islam-an tetap maju dan berkembang pesat yang mampu bertahan dan kokoh dengan jati dirinya, bahkan selalu mengalami peningkatan kualitas dan kuantitasnya.

Sedangkan konsep pendidikan Ki Hadjar yang berdasarkan Pancadarma kini sudah berubah, terpinggirkan dan mulai banyak ditinggalkan. Bahkan akhirakhir ini konsepsinya sangat berbeda dengan konsep dan kebijakan pendidikan nasional Indonesia, apalagi dalam situasi reformasi sekarang ini, dimana konsep pendidikan di Indonesia yang tengah ditinjau ulang untuk kemudian dihasilkan suatu rumusan konsep pendidikan yang sesuai dengan tuntutan zaman.

\section{KESIMPULAN}

Berdasarkan uraian dan analisis pada bab-bab sebelumnya, maka penelitian ini dapat disimpulkan sebagai berikut:

1. Pendidikan menurut Ki Hadjar Dewantara adalah tuntunan kepada anak-anak didik, agar dapat mencapai keselamatan dan kebahagiaan yang setingi-tinginya. Maksud dari konsepsi tersebut adalah, untuk mewujudnya masyarakat tertib, damai, berkeadilan sosial, mampu menyelamatkan dan membahagiakan manusia untuk keperluan perikehidupan yang dapat mengangkat derajat negara dan rakyatnya. Konsep pendidikan tersebut meskipun bertujuan untuk memberi tuntunan atau bimbingan ke arah kebaikan dan kebahagiaan, namun jika ditinjauan dalam perspektif pendidikan Islam, terdapat ketidaksesuaian. Hal ini dapat dilihat pada konsepsi Ki Hadjar yang tidak menekankan pada aspek ubudiyah dan tauhid. Sedangkan dalam pendidikan Islam, tuntunan ke arah tertib, damai, dan kebahagiaan setinggi-tingginya itu tidak boleh lepas dari nilainilai ibadah dan keimanan kepada Allah Swt, agar bahagia dunia dan akhirat.

2. Dasar yang dipakai Ki Hadjar dalam pelaksanaan pendidikannya adalah Pancadarma atau lima asas.Yang terdiri dari: 1. Asas Kemerdekaan, 2. Asas Kebangsaan, 3. Asas Kemanusiaan, 4. Asas Kebudayaan, dan 5. Asas Kodrat alam. Dasar Pancadarma tersebut, ternyata dalam perspektif pendidikan Islam terdapat ketidaksesuaian. Hal ini dikarenakan dasar pendidikan Ki Hadjar tidak menampilkan ruh dan nilai-nilai dasar Ilahiyah yang terdapat dalam al-Qur'an dan al-Hadits, melainkan bersumberkan pada budaya bangsa. Dimana dasar pendidikan yang tidak bermuarakan pada nilai-nilai Ilahiyah, berarti dasar pendidikan itu jauh dari nilai-nilai ketauhidan, karena dasar merupakan pandangan hidup yang melandasi seluruh aktifitas pendidikan, yang menyangkut masalah ideal dan fundamental, maka diperlukan landasan pandangan hidup 
yang kokoh dan komprehensif serta tidak mudah berubah karena diyakini memiliki kebenaran yang telah teruji oleh sejarah. Hal inilah yang membedakan antara dasar pendidikan Islam dengan dasar pendidikan Ki Hadjar.

3. Dari sudut pandang isinya, pendidikan Ki Hadjar menitik beratkan pada ajaran budi pekerti atau kesusilaan, di samping juga ajaran kemanusiaan (humanisme) dan kemerdekaan (kebebasan). Budi pekerti menurutnya merupakan ruh atau jiwa dari pengajarananya, karena budi pekerti dan pengajaran ibarat dua sisi mata uang yang tidak bisa dipisahkan. Hal yang demikian disebabkan pengajaran berarti membimbing tumbuhnya budi pekerti ke dalam hidup anak didik agar kelak menjadi manusia yang beradab. Ditinjau dalam perspektif pendidikan Islam, isi pendidikan Ki Hadjar tentang budi pekerti, kemanuisaan dan kebebasan ini juga tidak sesuai dengan pendidikan Islam. Hal ini dikarenakan konsep budi pekerti Ki Hadjar bertujuan pada nilai-nilai kemanusiaan belaka, tidak ada nilai keimanan dan ibadah. Sedangkan budi pekerti (akhlak) dalam Islam bermuatan nilai-nilai ibadah dan keimanan. Karena iman dan ibadah merupakan jiwa atau ruh dalam pendidikan Islam.

4. Sistem pendidikan Ki Hadjar merupakan keseluruhan komponen pendidikan yang saling terkait secara terpadu untuk mencapai tujuan yang dimaksud, sistem itu mengandung aspek: tujuan, kurikulum, metode, guru, murid, dan evaluasi, yang antara satu dengan lainnya saling berkaitan dan membentuk suatu sistem yang terpadu. Sistem pendidikan Ki Hadjar ditinjau dari perspektif Islam tidak sesuai dengan sistem pendidikan Islam, hal ini dikarenakan sistem pendidikan dalam Islam ditekankan pada pembentukan manusia muslim yang beriman, bertakwa serta bertauhid. Sedangkan sistem pendidikan Ki Hadjar ditekankan pada tujuan mengangkat harkat dan martabat serta kemajuan manusia, sehingga dapat berdiri kokoh sejajar dengan bangsa-bangsa lain, demi terwujudnya masyarakat tertib dan damai. Kurikulum pendidikan Ki Hadjar juga tidak sesuai dengan kurikulum pendidikan Islam, karena kurikulum Ki Hadjar tidak terkait dengan nilai-nilai intrisik agama dan akhlak Islam.

5. Pemikiran pendidikan Ki Hadjar bercorakkan nasionalistik-sekular. Nasionalistik, karena konsep pendidikannya berdasar dan bersumberkan pada prinsip budaya bangsa, yaitu pendidikan yang selaras dengan produk budaya bangsa, sebagaimana yang tertuang dalam asas Pancadharma yang bercorakkan kebudayaan dan kebangsaan. Ki Hadjar juga menghendaki suatu pendidikan yang tidak memihak golongan, pendidikanyang tidak bersumber dari satu agama tertentu, tetapi pendidikan yang merdeka, humanis, dan universal yang bisa merangkul semua unsur agama, keyakinan, golongan, suku, dan ras. Sekular, karena Ki Hadjar tidak memadukan konsep pendidikan yang ia gagas dengan nilai-nilai fundamental dalam Islam, yakni nilai ibadah "ta'abbudi" dan tauhid.

\section{UCAPAN TERIMA KASIH}

Ucapan terima kasih disampaikan kepada Ketua BAZNAS Republik Indonesia yang telah memberikan beasiswa untuk penelitian ini.

\section{REFERENCES}

[1] Abuddin Nata, Tokoh-tokoh Pembaruan Pendidikan Islam di Indonesia, Jakarta: PT Raja Grafindo Persada, 2005, hlm. 127. 
[2] Abdurrahman Surjomiharjo, Ki Hadjar Dewantara dan Taman Siswa dalam Sejarah Indonesia Modern, Jakarta: Sinar Harapan, 1986, hlm. 1.

[3] Moch. Tauchid, Ki Hadjar Dewantara Pahlawan dan Pelopor Pendidikan Nasional, Yogyakarta: Majlis Luhur Persatuan Tamansiswa, 1968, hlm. 73.

[4] Moch. Tauchid, Ki Hadjar Dewantara Pahlawan, hlm. 88.

[5] Kenji Tsuchiya, Democracy and Leadership: The Rise of The Taman Siswa Movement in Indonesia, Kyoto-Jepang: University of Honolulu Press, 1987, terjemahan H.B. Jassin, Demokrasi dan Kepemimpinan Kebangkitan Gerakan Taman Siswa, Jakarta: Balai Pustaka, 1992, hlm. V.

[6] Tamansiswa dalam berbagai tulisan Ki Hadjar Dewantara menggunakan kata "Taman" dan "Siswa" (Taman Siswa), dengan spasi. Lihat Ki Hadjar Dewantara dalam, Asas-asas dan Dasar-dasar Taman Siswa, hlm. 6. Demokrasi dan Leiderschap, hlm. 5. dan putusa putusan konggres XI tanggal 17-28 Desember 1971 dan putusan konggres XII tanggal 15-23 Desember 1975 Piagam dan Peraturan Besar Persatuan Taman Siswa. Tetapi karena berbagai pertimbangan dan kebijakan maka pengurus Majlis Luhur Taman Siswa, sepakat penulisan Taman Siswa berubah menjadi Tamansiswa "tanpa sepasi". Berdasarkan Keputusan Konggres XIV Persatuan Tamansiswa tahun 1984 dalam Peraturan Besar dan Piagam Persatuan Tamansiswa. Begitu juga terdapat dalam website resmi Majlis Luhur Tamansiswa Http://Tamansiswa.org.

[7] Abdurrahman Suryomiharja, Ki Hadjar Dewantara dan Tamansiswa, hlm. 1.

[8] Abuddin, Tokoh-tokoh Pembaruan, hlm. 126.

[9] Ibid., hlm. 126.

[10] Ibid., hlm. 127.

[11] Menurut Ki Hadjar Dewantara: Ing Ngarso Sung Tulodo, Ing Madya Mangun Karso, Tut Wuri Andayani. Memakai kata "Andayani". Lihat Ki Hadjar Dewantara dalam Asas-asas dan Dasardasar Tamansiswa, hlm. 23. Sedangkan menurut Abuddin Nata: Ing Ngarso Sing Tulodo, Ing Madya Mangun Karso, Tut Wuri Handayani. Memakai kata "sing" dalam sing tulodo dan "Handayani". Lihat Abuddin Nata dalam Tokoh-tokoh Pembaruan Pendidikan Islam di Indonesia, hlm. 127. dan menurut Amir Tengku Ramly memakai kata "mbangun" dalam Ing madya mbangun karso. Lihat di Refleksi Motivasi Pendidikan Ki Hadjar Dewantara, dalam Makalah yang disampaikan pada seminar nasional menyambut hari pendidikan nasional 2 mei 2010 di Palembang-Sumatera Selatan 6 mei 2010. dalam Http://Tamansiswa.org/VisiMisi.html.23.Pebruari.2012/13:20. Sedangkan menurut Ki Agus Purwanto dalam wawancara di museum Tamansiswa, 2 Juni 2012 prinsipnya sebagaimana dalam bahasa Jawa tempo dulu bahwa huruf "A" dibaca "Ha", maka kata Andayani dibaca Handayani. Jadi dalam hal ini memakai istilah Ing Ngarso Sung Tulodo, Ing Madya Mangun Karso, Tut Wuri Handayani.

[12] Abuddin Nata, Tokoh-tokoh Pembaruan, hlm. 127.

[13] Ki Priyo Dwiarso, Sistem Among Mendidik Sikap Merdeka Lahir Batin, dalam http://tamansiswa.org/profile-mainmenu-27/sejarah-tamansiswa-mainmenu32.html.12/06/2012-13:13.

[14] Amir Tengku Ramly, Refleksi Motivasi Pendidikan Ki Hadjar Dewantara, dalam Makalah yang disampaikan pada seminar nasional menyambut hari pendidikan nasional 2 mei 2010 di Palembang-Sumatera Selatan 6 mei 2010. dalam Http://Tamansiswa.org/VisiMisi.html.23.Pebruari.2012/13:20.

[15] Ki Hadjar Dewantara, menggunakan kata "andayani" dalam tut wuri andayani. Lihat Ki Hadjar Dewantara dalam, Asas-asas dan Dasar-dasar Tamansiswa, hlm. 23. dan Demokrasi dan Leiderschap, hlm. 9. Sementara Abuddin Nata menggunakan kata "handayani", lihat Abuddin Nata dalam Tokoh-tokoh Pembaruan Pendidikan Islam di Indonesia, hlm. 127.

[16] Ki Hadjar Dewantara, Asas-asas dan Dasar-dasar Tamansiswa, Yogyakarta: Majlis Luhur Tamansiswa, 1964, Cet III, hlm. 23.

[17] Ki Hadjar Dewantara, Demokrasi dan Leiderschap, Yogyakarta: Majlis Luhur Tamansiswa, 1964, Cet III, hlm. 9. 
[18] Mahrus Ahsani, Konstelasi Konsep Kodrat Alam dan Tut Wuri Handayani Ki Hadjar Dewantara Perspektif Pendidikan Islam.Tesis, Program Pascasarjana UIN Yogyakarta, 2004. hlm 13.

[19] Ibid., hlm. 13.

[20] Ahmad Sholeh, Relevansi Gagasan Sistem Among dan Tri Pusat Pendidikan Ki Hadjar Dewantara terhadap Pengembangan Pendidikan Islam di Indonesia, Tesis, Program Pascasarjana UIN Yogyakarta, 2002, hlm. 21.

[21] Bambang Sokawati Dewantara,, Ki Hadjar Dewantara Ayahku, Jakarta: Pustaka Sinar Harapan, 1989, hlm. 39.

[22] Ki Hadjar Dewantara, Asas-asas, hlm. 11.

[23] Abdurrahman Surjomiharjo, Ki Hajar Dewantara, Yogyakarta: Sinar Harapan, 1986, hlm. 97.

[24] Bambang Sokawati, Ki Hadjar Dewantara Ayahku, hlm. 39.

[25] Artawijaya, Acuan Hardiknas Ki Hadjar Dewantara atau KH Ahmad Dahlan, dalam http://fkip.uad.ac.id/2011/08/ diakses 29 Februari 2012.

[26] Ibid., diakses 29 Februari 2012.

[27] Ki Hadjar Dewantara, Asas-asas, hlm. 29.

[28] Abuddin, Tokoh-tokoh, hlm. 128.

[29] Theo Riyanto, Ajaran Ki Hadjar Dewantara Mulai Ditinggalkan, (Online), Metrotvnews.com.2-Mei-2010.22:27.wib.Yogyakarta.nusantara. Html 20 Maret 2011.

[30] Abuddin Nata, Tokoh-tokoh, hlm. 127.

[31] M. Fadhil al-Jamali, Filsafat Pendidikan dalam al-Qur'an, Surabaya: Bumi Ilmu, 1986, hlm. 27.

[32] Arifin, Ilmu Pendidikan Islam, Jakarta: Bumi Aksara, 1993, hlm. 30.

[33] M. H. al-Hamid al-Husaini, membangun Peradaban: Sejarah Muhammad Saw Sejak Sebelum Diutus Menjadi Nabi, Bandung: Pustaka Hidayah, 2000, hlm. 345-346.

[34] Hanun Asrohah, Sejarah, hlm. 12.

[35] Muhammad 'Athiyyah al-Abrasyi, Prinsip-prinsip Dasar Pendidikan Islam, Bandung: Pustaka Setia, 2003, hlm. 22.

[36] Achmadi, Ideologi Pendidikan Islam, Yogyakarta, Pustaka Pelajar, hlm. 31.

[37] Ibid., hlm.85.

[38] Hadari Nawawi, Metodologi Penelitian Bidang Sosisal, Yogyakarta: Gajah Mada University Press, 2003, hlm. 133.

[39] Robert C. Bodgan dan Sari Knopp Biklen, Qualitative Research for Education: An Introduction to Theory and Methods, London: Allyn and Bacon, 1998, hlm. 4-5.

[40] Abuddin Nata, Metodologi Studi Islam, Jakarta: Raja Grafindo Persada, 1998, hlm. 46.

[41] Endin Mujahidin, Metodologi Penelitian dan Penulisan Ilmiah, dalam Mata kuliah metodologi penelitian, disampaikan pada kuliah Pascasarjana Doktoral di Universitas Ibn Khaldun, Bogor, pada tanggal 26 Juni 2010.

[42] Komaruddin, Metode Penelitian Kualitatif, Yogyakarta: Pustaka Pelajar, 1991, hlm. 72.

[43] Ibid., hlm.79.

[44] Winarno Surahmat, Penelitian Ilmiah Dasar: Metode dan Teknik, Bandung: Tarsito, 1982, hlm. 134.

[45] Saifuddin Azwar, Metode Penelitian, Yogyakarta: Pustaka Pelajar, 2010, hlm. 91.

[46] Saifuddin Azwar, Metode, hlm. 91.

[47] Sumardi Suryabrata, Metode Penelitian, Jakarta: Rajawali Press, 1998, hlm. 94.

[48] Ibid., hlm. 198.

[49] Hadari Nawawi, Metode Penelitian Bidang Sosial, Yogyakarta: Gajah Mada University Press, 1993, hlm. 31.

[50] S. Margono, Metodologi Penelitian Pendidikan, Jakarta: Rineka Cipta, 2005, hlm. 38.

[51] Lihat Mahrus Ahsani, Konstelasi Konsep Kodrat Alam dan Tut Wuri Handayani Ki Hadjar Dewantara Perspektif Pendidikan Islam, Tesis, Program Pascasarjana konsentrasi Pemikiran Pendidikan Islam UIN Sunan Kalijaga Yogyakarta, 2004.

[52] Lihat Ahmad Sholeh, Relevansi Gagasan Sistem Among dan Tri Pusat Pendidikan Ki Hadjar Dewantara Terhadap Pengembangan Pendidikan Islam di Indonesia. Tesis, Program Pascasarjana konsentrasi Sejarah Pendidikan Islam UIN Sunan Kalijaga Yogyakarta, 2002. 
[53] Lihat Widayati Pujiastuti, Konsep Manusia Sebagai Pamong Menurut Ki Hadjar Dewantara, Tesis, Program Pascasarjana Studi Ilmu Filsafat Universitas Gajah Mada Yogyakarta, 1998.

[54] Noordiana, Operet "Arya Penangsang Gugur" di Tamansiswa Yogyakarta. Tesis, Program Pascasarjana Institut Seni Indonesia (ISI) Surakarta Program Studi Pengkajian Seni Minat Tari, Surakarta, 2006.

[55] Lihat Kenji Tsuchiya, Democracy and Leadership: The rise of the Taman Siswa Movement in Indonesia, Disertasi, (ditulis dalam bahasa jepang yang sudah diterjemahkan dalam bahasa Inggris), Kyoto - Jepang, 1987. dan diterjemhakan kembali ke dalam Bahasa Indonesia oleh H.B. Jassin dengan judul Demokrasi dan Kepemimpinan Kebangkitan Gerakan Tamansiswa, Jakarta: Balai Pustaka, 1992.

[56] Sholehan, Pendidikan Menurut Ki Hadjar Dewantara: Konsepsi Pancadarma Ki Hadjar Dewantara Ditinjau dari Sudut Pandang Pendidikan Islam. dalam http://blog.sunanampel.ac.id/sholehan/2011/05/18/pendidikan-menurut-ki-Hadjar-dewantoro/html. Diakses 12 Juni 2012, 13:32.

[57] Abuddin Nata, Tokoh-tokoh, hlm. 155-156.

[58] Ki Hadjar Dewantara, Karya Ki Hadjar Dewantara: Bagian Pertama, Pendidikan, Yogyakarta: Majlis Luhur Tamansiswa, 1967, hlm. 20.

[59] Hasbullah, Dasar Ilmu Pendidikan, Jakarta: PT RajaGrasindo Persada,?2005, hlm. 15.

[60] Muhaimin, Paradigma Pendidikan Islam: Upaya Mengefektifkan Pendidikan Agama Islam di Sekolah, Bandung: PT Remaja Rosdakarya, 2008, Cet IV, hlm. 29.

[61] Achmadi, Ideologi Pendidikan Islam, Yogyakarta: Pustaka pelajar, hlm. 85.

[62] Muhaimin, Paradigma Pendidikan, hlm. 29-30.

[63] Achmadi, Ideologi Pendidikan Islam, hlm. 85.

[64] Ki Hadjar Dewantara, Asas-asas daan Dasar-dasar Tamansiswa, hlm. 25.

[65] Ki Hadjar Dewantara, Asas-asas daan Dasar-dasar Tamansiswa, hlm. 30.

[66] Sholehan, Pendidikan Menurut Ki Hadjar Dewantara: Konsepsi Pancadarma Ki Hadjar Dewantara Ditinjau dari Sudut Pandang Pendidikan Islam. dalam http://blog.sunanampel.ac.id/sholehan/2011/05/18/pendidikan-menurut-ki-Hadjar-dewantoro/html. Diakses 12 Juni 2012, 13:32.

[67] Hasan Langgulung, Beberapa Pemikiran Tentang Pendidikan Islam, Jakarta: Pustaka AlHusna, 1983, hlm. 61.

[68] A. Susanto, Pemikiran Pendidikan Islam, Jakarta: Azmi, 2009, hlm 123.

[69] Ibid., hlm. 124.

[70] Marcel A. Boisard, L'Humanisme de L'Islam yang diterjemahkan oleh H.M. Rasjidi berjudul Humanisme dalam Islam, Jakarta: Bulan Bintang, 1989, hlm. 99.

[71] Ibid., hlm. 99

[72] Marcel A. Boisard, L'Humanisme de L'Islam, hlm. 101.

[73] Ibid., hlm. 99.

[74] Ibid., hlm. 100.

[75] Ki Hadjar Dewantara, Asas-asas, hlm. 30

[76] Sholehan, Pendidikan Menurut Ki Hadjar, hlm. 14.

[77] Ki Hadjar Dewantara, Asas-asas, hlm. 31.

[78] Ki Hadjar Dewantara, Bagian PertamaPendidkan, hlm. 56.

[79] Sholehan, Pendidikan Menurut Ki Hadjar Dewantara, hlm. 15.

[80] Marcel A. Boisard, L'Humanisme de L'Islam, hlm. 93.

[81] Ibid., hlm. 104-105.

[82] Marcel A. Boisard, L'Humanisme de L'Islam, hlm. 105.

[83] Marcel A. Boisard, L'Humanisme de L'Islam , hlm. 94-95.

[84] Ibid., hlm. 95.

[85] Ibid., hlm. 93.

[86] Ibid., hlm. 94.

[87] Marcel A. Boisard, L'Humanisme de L'Islam , hlm. 93.

[88] Ibid., hlm. 102.

[89] Marcel A. Boisard, L'Humanisme de L'Islam , hlm. 102-103. 
[90] Marcel A. Boisard, L'Humanisme de L'Islam, hlm. 101.

[91] Ibid., hlm. 108.

[92] Ki Hadjar Dewantara, Asas-asas, hlm. 31.

[93] Ki Hadjar Dewantara, Asas-asas dan Prinsip Taman Siswa, Yogyakarta: Majelis Luhur Persatuan Taman Siswa, 198, hlm. 31.

[94] Ibid., hlm. 352.

[95] al-Saibani, Falsafah, 183.

[96] Abdurrahman al-Nahlawi, Usulut Tarbiyah al-Islamiyah wa Asalibuha atau Pendidikan Islam di Rumah, Sekolah, dan Masyarakat, terj. Shihabuddin, Jakarta: Gema Insani Press, 1995, hlm. 28

[97] Wan Mohd. Nor Wan Daud, The Concept of Knowledge in Islam and it's Implication for Education in a Developing Country atau Konsep Pengetahuan dalam Islam, terj. Munir, Bandung: Pustaka, 1997, Cet I, hlm. 260.

[98] M. Nasir Budiman, Pendidikan dalam Perspektif Islam, Jakarta: Madani press, 2001, hlm. 4.

[99] Achmadi, Ideologi Pendidikan, hlm. 88.

[100]Amin Rais, Cakrawala Islam, dalam Achmadi, Ideologi, 1998, hlm. 19.

[101]Ki Hadjar Dewantara, Bagian Pertama (Pendidikan), Yogyakarta: Majlis Luhur Tamansiswa, 1967, hlm. 20.

[102]Abuddin Nata, Tokoh-tokoh Pembaruan Pendidikan Islam di Indonesia, Jakarta: Rajagrafindo Persada, 2005, 56.

[103]Ki Hadjar Dewantara, Karya Ki Hadjar Dewantara, hlm. 44.

[104]Abuddin Nata, Tokoh-tokoh Pembaruan, hlm. 57.

[105]Abdurrahman Surjomiharjo, Ki Hajar Dewantara dan Taman Siswa dalam Sejarah Indonesia Modern, Yogyakarta: Sinar Harapan, 1986, hlm. 67.

[106]Ki Hadjar Dewantara, Asas asa, hlm. 34.

[107]Adian Husaini, Pendidikan, hlm. 67.

[108]M. Athiyah al-Abrasyi, Prinsip-prinsip Dasar Pendidikan Islam, Bandung: Pustaka Setia, 2003, hlm. 34

[109]Abdurrahman al-Nahlawi, Pendidikan Islam di Rumah, Sekolah dan Masyarakat, Jakarta: GIP, 2005, 26.

[110]Muhaimin, Paradigma Pendidikan Islam, Bandung: Rosdakarya, 2008, hlm. 98.

[111]Ki Hadjar Dewantara, Asas-asas, hlm. 31.

[112]Ki Hadjar Dewantara, Bagian Pertama Pendidkan, hlm. 56.

[113]Sholehan, Pendidikan Menurut Ki Hadjar Dewantara, hlm. 15.

[114]Ki Hadjar Dewantara, Bagian Pertama Pendidikan, hlm. 33.

[115]Sholehan, Pendidikan Menurut Ki Hadjar Dewantara: Konsepsi Pancadarma Ki Hadjar Dewantara Ditinjau dari Sudut Pandang Pendidikan Islam. dalam http://blog.sunanampel.ac.id/sholehan/2011/05/18/pendidikan-menurut-ki-Hadjar-dewantoro/html. Diakses 12 Juni 2012, 13:32.

[116] Hasan Langgulung, Beberapa Pemikiran Tentang Pendidikan Islam, Jakarta: Pustaka AlHusna, 1983, hlm.61.

[117]A. Susanto, Pemikiran Pendidikan Islam, Jakarta: Azmi, 2009, hlm 123.

[118]Ibid., hlm. 124.

[119] Marcel A. Boisard, L'Humanisme de L'Islam yang diterjemahkan oleh H.M. Rasjidi berjudul Humanisme dalam Islam, Jakarta: Bulan Bintang, 1989, hlm. 99.

[120]Ibid., hlm. 99.

[121]Marcel A. Boisard, L'Humanisme de L'Islam, hlm. 100.

[122]Ki Hadjar Dewantara, Bagian Pertama, hlm.30.

[123] Ki Hadjar Dewantara, Bagian Pertama, hlm. 31.

[124]Abdurrahman al-Nahlawi, Pendidikan Islam, hlm. 84.

[125]Adian Husaini, Pendidikan Islam Membentuk Manusia Berkarakter dan Beradab, Depok: Komunitas Nuun-Pps UIKA Bogor, 2011, hlm. 3-4.

[126]Ibid., hlm. 3-4.

[127]Ki Agus Purwanto, Wawancara di Museum Dewantara Griya Kirti, Yogyakarta, pada Jum'at 15 Juni 2012.

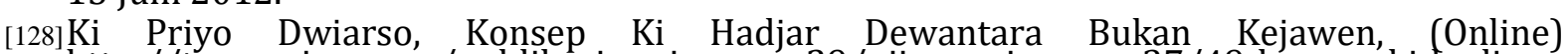
http://tamansiswa.org/publikasi-mainmenu-29/pijar-mainmenu-37/49-konsep-ki-hadjardewantara-bukan-kejawen.html 7 April 2012.

[129]Ibid.,

[130]Al-Ghazali dalam Syamsuddin Arif, Filsafat, hlm. 14.

[131]Hasbullah, Dasar Ilmu Pendidikan, hlm. 15. 
[132]Didin Hafidhuddin, Tafsir Hadits Pendidikan, hlm. 9-10.

[133]Abuddin Nata, Tokoh-tokoh, hlm. 135.

[134]Ki Hadjar Dewantara, Pendidikan, hlm. 80.

[135]Ki Hadjar Dewantara, Pendidikan, hlm. 80.

[136] Muhaimin, Konsep Pendidikan Islam, Solo: Ramadhani, 1993, hlm. 33.

[137]Abdurrahman al-Nahlawi, Pendidikan Islam, hlm, 196.

[138]M. Athiyyah al-Abrasyi, Prinsip-prinsip Dasar, hlm. 169.

[139]Abdul Majid, Perencanaan Pembelajaran, Bandung: Remaja Rosdakarya, 2009, hlm. 135.

[140]Abdullah Aly, Tujuan Pendidikan Islam, dalam Bahan Ajar P3I, pada 10 Agustus 2010.

[141]Ki Hadjar Dewantara, Pendidikan, hlm. 485.

[142] Ki Hadjar Dewantara, Asas-asas, hlm. 27.

[143]Ki Hadjar Dewantara, Pendidikan, hlm. 25.

[144]Ibid., hlm 25-26.

[145]Arifin, Ilmu Pendidikan Islam, hlm. 228.

[146]Abdullah Aly, Tujuan Pendidikan Islam, hlm, 7.

[147]Agus Handoko, Muhasabah Diri Menggapai Masa Depan, (Online), http://www.pesantrenvirtual.com/index.php?Itemid=59\&catid=4:hikmah\&id=1247:muhas 2012, 16:35. [148]Ibid.

[149]Bambang Sokawati, Ki Hadjar Dewantara Ayahku, hlm. 39.

[150]Moch. Tauchid, Ki Hadjar Dewantara Pahlawan, hlm. 88.

[151]Lihat Risalah Sidang BPUPKI yang diterbitkan Sekretaris Negara RI, hlm. 216, dalam Adian Husaini, Wajah Peradaban Barat: dari Hegemoni Kristen ke Dominasi Sekular-Liberal, Jakarta: Gema Insani, 2005, hlm. 375-376.

[152]Ibi., hlm. 376.

[153]Ibi., hlm. 376.

[154]Adian Husaini, Wajah Peradaban Barat, hlm. 377.

[155]Sebagai contoh, pada tanggal 10 Agustus 2000, tiga tokoh Islam Indonesia, yaitu Ketua Umum PBNU Hasyim Muzadi, Ketua Umum PP Muhammadiyah Syafi'i Ma'arif, dan Nurcholis Madjid mebuat pernyataan bersama. Isinya: menolak masuknya Piagam Jakarta dalam UUD 45. Dengan beberapa alasan mereka. Lihat: Adian Husaini, Penyesatan Opini, dan Wajah Peradaba Barat, Jakarta: Gema Insani, 2005, hlm. 378.

[156]Artawijaya, Acuan Hardiknas Ki Hadjar Dewantara atau KH Ahmad Dahlan, dalam http://fkip.uad.ac.id/2011/08/, diakses 29 Februari 2012.

[157]Artawijaya, Acuan Hardiknas Ki Hadjar Dewantara atau KH Ahmad Dahlan, dalam http://fkip.uad.ac.id/2011/08/, diakses 29 Februari 2012.

[158]Ibid.

[159]Artawijaya, Acuan Hardiknas Ki Hadjar Dewantara atau KH Ahmad Dahlan, dalam http://fkip.uad.ac.id/2011/08/, diakses 29 Februari 2012.

[160]Ibid

[161]Ki Hadjar Dewantara, Asas-asas, hlm. 29.

[162] Artawijaya, Acuan Hardiknas Ki Hadjar Dewantara atau KH Ahmad Dahlan, dalam http://fkip.uad.ac.id/2011/08/ diakses 29 Februari 2012.

[163] Moch. Tauchid, Ki Hadjar Dewantara Pahlawan dan Pelopor Pendidikan Nasional, Yogyakarta: Majlis Luhur Persatuan Tamansiswa, 1968, hlm. 88.

[164]Moch. Tauchid, Ki Hadjar Dewantara Pahlawan dan Pelopor Pendidikan Nasional, Yogyakarta: Majlis Luhur Persatuan Tamansiswa, 1968, hlm. 73. [165] Theo Riyanto, Ajaran Ki Hadjar Dewantara Mulai Ditinggalkan,
Metrotvnews.com.2-Mei-2010.22:27.wib.Yogyakarta.nusantara. Html 20 Maret 201 .

[166]Abuddin Nata, Tokoh-tokoh, hlm. 127.

[167]Abuddin Nata, Tokoh-tokoh, hlm. 127.

[168]WWW. Kompas.com/webmetrics/ Juli-2012, diakses 26 Januari 2013.

[169] Http//www.umm.ac.id, diakses 26 Januari 2013.

[170]Http//www.umm.ac.id, diakses 26 Januari 2013. 